\author{
UNIVERSIDADE DE SÃO PAULO \\ FACULDADE DE ODONTOLOGIA DE BAURU
}

JORGE FRANCISCO FIAMENGUI FILHO

Avaliação da remodelação do rebordo alveolar após exodontia minimamente traumática e utilização de enxerto xenógeno para preservação alveolar 

JORGE FRANCISCO FIAMENGUI FILHO

\section{Avaliação da remodelação do rebordo alveolar após exodontia minimamente traumática e utilização de enxerto xenógeno para preservação alveolar}

Tese apresentada a Faculdade de Odontologia de Bauru, da Universidade de São Paulo, como parte dos requisitos necessários para obtenção do título de DOUTOR em Ciências Odontológicas Aplicadas, área de concentração Reabilitação Oral.

Orientador: Prof. Dr. Sebastião Luiz Aguiar Greghi

\section{Versão Corrigida}

\section{BAURU}


Fiamengui Filho, Jorge Francisco

F442a Avaliação da remodelação do rebordo alveolar após exodontia minimamente traumática e utilização de enxerto xenógeno para preservação alveolar / Jorge Francisco Fiamengui Filho -- Bauru, 2015.

94 p. : il. ; $31 \mathrm{~cm}$.

Tese (Doutorado) -- Faculdade de Odontologia de Bauru. Universidade de São Paulo.

Orientador: Prof. Dr. Sebastião Luiz Aguiar Greghi

Nota: A versão original desta tese encontra-se disponível no Serviço de Biblioteca e Documentação da Faculdade de Odontologia de Bauru - FOB/USP.

Autorizo, exclusivamente pra fins acadêmicos e científicos, a reprodução total ou parcial desta tese, por processos fotocopiadores e/ou meios eletrônicos.

Assinatura do autor:

Data:

COMITÊ DE ÉTICA E PESQUISA FOB USP

CAAE: 03016412.7 .0000 .5417

PARECER: 48497

APROVADO EM 04/06/2012 


\section{DEDICATÓRIA}

Aos mens pais Jorge e María José, mens maiores exemplos nesta vida. Sem o incentivo e amor de vocês, nada disso sería possivel. $E$ ́ muito bom poder compartithar cada conquista com vocês!!

À minha esposa e companheira Livia, que conheci nos corredores desta Faculdade e escothi para viver ao men lado todos os momentos de minha vída! Mew amor, sou louco por você! Sew incentivo diário é meu combustivel para atingir nossos objetivos. Te amo!

Aos meus irmãos Daniel e Ivan, pessoas que gosto muito e que sinto muita falta da convívêncía diáría.

Aos mens sogros Sérgio e Lígia, pelo incentivo diário e todo apoio. Vocês são mens pais do Ceará!!

Ao mew afithado Felipe, por me chamar de Teteo. 



\section{AGRADECIMENTOS ESPECIAIS}

Ao men querido orientador, Prof. Dr. Sebastião Luiz Aguiar Greghi. Hoje, mais do que nunca, só tenho a agradecer o professor, orientador e amigo que o senhor é e sempre será! Obrigado pela orientação neste trabalho, pelas conversas e pelos conselhos. Observar o senhor trabalhando nas clinicas e orientando os alunos contribuiu muito para que en pudesse aprender o que realmente é ser um professor. Minha admiração pelo senhor vem desde a primeira aula de Periodontia, em 2003, no anfiteatro 2 desta Faculdade. Foi um privilégio muito grande poder ter $\sigma$ senhor como orientador. 



\section{AGRADECIMENTOS}

A Deus, por me abençoar diariamente, com proteção e força, para cumprir as atividades diárias e poder superar todos os desafios.

À Faculdade de Odontologia de Bauru, que, desde 2002, é minha segunda casa, local onde sempre fui muito bem tratado por todos. Aqui reatizei toda minha formação profissional e acadêmica, fiz muitos amigos e conheci minha esposa. Serei eternamente grato.

Aos professores da Periodontia, Prof. Dr. Euloir Passanezi, Profa. Dra. Maria Lucia Rubo de Rezende, Profa. Dra. Adriana Campos Passanezi SantAna, Profa. Dra. Carla Andreott Damante e Mariana Schutzer Ragghiant Zangrando por todos os conhecimentos transmitidos;

À professora Ana Lúcia Pompéia Fraga de Almeida, por toda confiança desde os tempos do HRAC e pela amizade que preservamos.

A Edilaine, Marcão, Ivana e a todos os pós-graduandos da Periodontia e Prótese, pela ajuda diáría e convivencia durante esse periodo;

Ao Setor de Tríagem da FOB, pelo cuidado e colaboração para $\sigma$ desfecho desse trabalho;

Aos meus pacientes que contribuiram imensamente para realização deste trabatho e mais ainda para o meu enriquecimento profissional;

Aos professores Carlos Fitho e Lívia Barros pela amizade e confiança no trabalho diário na coordenação do curso de Odontologia da FCRS. 

Aos alunos da Faculdade Católica de Quixadá, pelo incentivo diário e amizade. Poder transmitir os conhecimentos que adquiri em Bauru a vocês é gratificante.

Ao ProfDr. Ricardo Andrés Landázuri, por todo apoio e amizade.

Ao Prof Dr. Newton Maciel oliveira, tio querido, pelo incentivo e ajuda na parte histológica deste trabalho.

Aos mens muitos colegas e amigos de profissão, com os quais me formei, estudei e trabalho diariamente.

A Baumer $^{\circledR}$ e a Neodent ${ }^{\circledR}$ por disponibitizar os materiais necessários para a execução desta pesquisa.

A todos que direta ou indiretamente contribuiram para reatização deste trabatho e pela minha formação acadêmica. 

“A felicidade às vezes é uma benção, mas geralmente é uma conquista" 

RESUMO 



\section{RESUMO}

\section{Avaliação da remodelação do rebordo alveolar após exodontia minimamente traumática e utilização de enxerto xenógeno para preservação alveolar}

Introdução: Após a exodontia, a cicatrização natural do alvéolo provoca alterações dimensionais no rebordo alveolar, com diminuição dos tecidos moles e duros. Diferentes técnicas podem ser utilizadas para tentar diminuir essas alterações, com a intenção de facilitar a reabilitação estética e funcional com implantes, principalmente em áreas de dentes anteriores.

Objetivos: Os objetivos deste estudo foram verificar a eficácia da utilização do material de origem xenógena Orthogen ${ }^{\circledR}$ na preservação do rebordo alveolar pós-exodontia e avaliar as características histológicas após 4 meses de reparo.

Materiais e Métodos: 20 pacientes foram divididos aleatoriamente em 2 grupos, de acordo com a abordagem que iriam receber após a exodontia de uma raiz residual. No grupo teste, os alvéolos foram preenchidos com Orthogen ${ }^{\circledR}$ e selados com EGL (Enxerto Gengival Livre). No grupo controle, um coágulo foi preservado no alvéolo e o mesmo também foi selado com EGL, sem a utilização do Orthogen ${ }^{\circledR}$. Em ambos os grupos as exodontias foram realizadas de maneira minimamente traumática, com o Kit de Extração Atraumática Neodent ${ }^{\circledR}$. Modelos de gesso obtidos antes das exodontias (tempo 1) e após 4 meses (tempo 2), momentos antes da instalação dos implantes, foram utilizadas para as medidas dimensionais, através do escanemento dos modelos e medidas no programa Orthoanalyzer ${ }^{\circledR}$. Amostras ósseas obtidas após 4 meses de reparo foram utilizadas para a análise histológica descritiva.

Resultados: Os resultados demonstraram que, após 4 meses de reparo alveolar, os dois grupos apresentaram remodelação do rebordo alveolar e diminuição nas medidas realizadas. Porém, a remodelação do rebordo foi mais evidente no grupo controle (coágulo). Histologicamente foi possível observar formação de novo osso ao redor das partículas do Orthogen ${ }^{\circledR}$.

Conclusões: A utilização do Orthogen ${ }^{\circledR}$ para preenchimento dos alvéolos e preservação do rebordo alveolar foi eficaz na diminuição das alterações dimensionais nos tecidos duro e mole do rebordo alveolar pós-exodontia.

Palavras-chave: Extração dentária, Processo alveolar, Transplante ósseo, Biomateriais, Implantes dentários. 

Abstract 



\section{ABSTRACT \\ Dimensional changes of alveolar bone in extraction sockets, after minimally traumatic extraction and socket fill with xenogenic bone}

Introduction: After tooth extraction, the natural healing of the socket is followed by dimensional changes of ridge contour, with marked reduce of hard and soft tissues. Socket preservation techniques can be used to improve functional and esthetics of the dental implants in this areas, especially in anterior teeth areas.

Objectives: The aims of this study are to verify the efficacy of use Orthogen ${ }^{\circledR}$ to ridge preservation and analysis the histological characteristics after 4 months repair of the sockets.

Material and Methods: 20 patients were randomly distributed in 2 groups, according with the treatments. In test group, the sockets were filled with Orthogen ${ }^{\circledR}$ and closed with a gingival free graft. In control group, the clots were preserved into the socket and free gingival graft was sutured in the deepithelialized marginal tissue of the socket. Stone casts were used to analyze the ridge dimensional changes with the Orthoanalyzer ${ }^{\circledR}$ software. After 4 months, bone samples were obtained during the dental implant procedure and were used to describe the histological characteristics.

Results: The results showed that, after 4 months of wound healing, both groups showed a decrease in the measurements. However, the remodeling of the ridge was most evident in the control group (clot). Histological images showed the formation of new bone around the Orthogen ${ }^{\circledR}$ particles.

Conclusion: The use of Orthogen ${ }^{\circledR}$ to socket preservation can collaborate to reduce the dimensional changes of the hard and soft tissue in post-extraction alveolar ridge sites.

Keywords: Extraction socket, Socket preservation, graft, Ridge preservation, Xenogenic bone graft 



\section{LISTA DE ILUSTRAÇÕES}

Figura 1. Procedimento de exodontia minimamente traumática e preenchimento do alvéolo com biomaterial realizado nos pacientes do Grupo 1 / Teste. a) componentes do kit de extração atraumática Neodent. b) Foto frontal inicial contendo remanescente radicular fraturado. c) Preparo do interior da conduto radicular com broca helicoidal de $1.3 \mathrm{~mm}$. d) Inserção do componente de tração no interior do conduto radicular preparado. e) Dispositivo tracionador apoiado nos dentes laterais, pronto para iniciar a exodontia no sentido apico-coronal. f) Raiz sendo extraída pelo tracionamento. g) Alvéolo dentário pós-exodontia. Notar a completa preservação dos tecidos circunjacentes. h) Preenchimento do alvéolo com osso particulado bovino (Orthogen). i) Sutura do EGL proveniente do palato, vedando o alvéolo.

Figura 2. Procedimento de exodontia minimamente traumática e selamento do alvéolo apenas com o enxerto gengival livre, mantendo apenas o coágulo no interior do alvéolo. a) Foto frontal inicial. b) Parte cororadicular do elemento 11 fraturado. c) Foto clínica do remanescente radicular fraturado. d) Preparo do interior do conduto radicular com broca helicoidal de $1.3 \mathrm{~mm}$. e) Tracionador instalado no interior do canal radicular. F) Momento da exodontia, com o extrator apoiado nos dentes laterais. g) Foto oclusal do alvéolo dentário após a exodontia, mostrando a estabilização de um coágulo sanguíneio no interior do alvéolo. h) EGL posicionado sobre o alvéolo. i) Sutura do EGL proveniente do palato, vedando o alvéolo.

Figura 3. Amostra óssea retirada com broca trefina de $3 \mathrm{~mm}$, do local do alvéolo cicatrizado, momentos antes à instalação do implante dentário no mesmo local.

Figura 4. Imagens do modelo virtual sendo analisado no programa orthoanalyzer. O corte foi realizado no centro do rebordo alveolar desdentado, obtendo uma imagem do rebordo central remanescente.

Figura 5. Imagens obtidas dos cortes realizados nos modelos. a) Rebordo alveolar; b) espessura do rebordo; c) espessura do centro do rebordo; d) perímetro da área cervical do rebordo; e) área cervical do rebordo; f) área total do rebordo

Figura 6. a) Remanescentes radiculares de um primeiro pré-molar superior cariado e com fratura radicular. b) Partes das raízes após a exodontia minimamente traumática 

Figura 7. a) Imagem de amostra do grupo controle, mostrando raiz residual do dente 11 antes de ser extraída. b) Rebordo cicatrizado após exodontia minimamente traumática + EGL (Grupo Controle - 4 meses)

Figura 8. a)Imagem de amostra do grupo teste, mostrando raiz residual do dente 21 antes de ser extraída. b) Rebordo cicatrizado após exodontia minimamente traumática + preenchimento do alvéolo com Ortogen + EGL (Grupo Teste - 4 meses). Notar uma mínima esfoliação de partículas do material enxertado no centro do alvéolo.

Figura 9. Figura 1. Imagem de alvéolo não enxertado (grupo controle). Uma camada de tecido ósseo cortical foi formada na parte coronal do alvéolo (OC). Na parte central do alvéolo, o trabeculado ósseo com a presença de grandes espaços medulares (EM) e vasos sanguíneos (VS) caracterizam a presença do novo osso (NO) Também pode-se observar presença de osso cortical (OCM) remanescente na parte apical do alvéolo. H.E. (Aumento original x 4).

Figura 10. Figura 2. Imagem de alvéolo não enxertado (grupo controle). Podemos observar osso primário (NO), caracterizado por fibras colágenas dispersas e presença de inúmeros osteócitos. Ao redor, presença de osteoblastos, indicando contínua neoformação óssea. Também é possível observar tecido conjuntivo (TC) com presença de células mesenquimais, adipocitos (AD), amplos espaços medulares (EM) e grande quantidade de vasos sanguíneos (VS) H.E. (Aumento original x 10).

Figura 11. Figura 3. Imagem do alvéolo não enxertado (grupo controle). Em destaque, osso neoformado com a presença de osteócitos (OCT), vasos sanguíneos e linhas cimentantes (LC), que demonstram que, após 4 meses, já houve remodelação do tecido ósseo neoformado. $\mathrm{Na}$ margem óssea, pode-se observar osteoblastos (OBT). H.E. (Aumento original x 14).

Figura 12. Imagem do alvéolo enxertado com o biomaterial (grupo teste) após 4 meses. Podemos observar, da esquerda para direita, o epitélio gengival queratinizado (EQ), tecido conjuntivo denso (TC) e o trabeculado do novo osso formado (NO) na vizinhança das particulas do biomaterial (BIO) H.E. (Aumento original x 4).

Figura 13. Fotomicrografia do alvéolo enxertado com o biomaterial (grupo teste), após 4 meses. Podemos observar a ilhas de neoformação óssea (NO) ao redor das partículas de biomaterial (BIO), presença de vasos sanguíneos e espaços medulares, ausência de células gigantes e sinais inflamatórios. H.E. (Aumento original x 4). 

Figura 14. Imagem do alvéolo enxertado com o biomaterial (grupo teste), após 4 meses. No detalhe, pode-se observar formação de novo osso na superfície das partículas do biomaterial (BIO), demonstrando a integração do enxerto como osso. H.E. (Aumento original x 10).....

Figura 15. Imagem do alvéolo enxertado com o biomaterial (grupo teste), após 4 meses. É possível observar as partículas do biomaterial com lacunas de hawship (espaços ocupados pelos antigos osteócitos) e neoformação óssea (NO) ao redor das partículas do biomaterial (BIO), mostrando seu potencial de osteocondução e osteoindução. H.E. (Aumento original x 14) .... 



\section{LISTA DE GRÁFICOS}

Gráfico 1. Distribuição das raízes residuais extraídas na arcada dentária superior dos pacientes incluídos no estudo.

Gráfico 2. Duração total do tempo de exodontia (em minutos). É possível notar que, em 15 casos, os procedimentos foram concluídos em no máximo 3 minutos.

Gráfico 3. Comparação entre as espessuras do topo do rebordo alveolar antes (tempo 1) e 4 meses após a exodontia (tempo 2). A perda em espessura no topo do rebordo foi significantementeno maior no grupo controle $(\mathrm{p}<0,001)$.

Gráfico 4. Comparação entre as espessuras do centro do rebordo alveolar antes (tempo 1) e 4 meses após a exodontia (tempo 2). A perda em espessura do centro do rebordo foi significantemente maior no grupo controle $(\mathrm{p}<0,001)$. 58

Gráfico 5. Comparação entre o perímetro do rebordo alveolar antes (tempo 1) e 4 meses após a exodontia (tempo 2). O perímetro do rebordo diminuiu significantemente no grupo controle $(p<0,001)$. 58

Gráfico 6. Comparação entre as áreas cervicais antes (tempo 1) e 4 meses após a exodontia (tempo 2). Houve área cervical do rebordo diminuiu significantemente mais no grupo controle $(p<0,001)$.

Gráfico 7. Comparação entre as áreas totais do rebordo alveolar antes (tempo 1) e 4 meses após a exodontia (tempo 2). Houve uma diminuição da área total significantemente maior no grupo controle $(\mathrm{p}<0,001)$. 59 



\section{LISTA DE TABELAS}

Tabela 1. Medidas realizadas nos modelos virtuais do grupo controle (Coágulo + EGL) .55

Tabela 2. Medidas realizadas nos modelos virtuais do grupo teste (Orthogen

+ EGL) 



\section{SUMÁRIO}

1 INTRODUÇÃO 17

2 REVISÃO DA LITERATURA .21

2.1 CICATRIZAÇÃO NATURAL DO ALVÉOLO APÓS EXODONTIA. 23

2.2 ASPECTOS IMPORTANTES DA CICATRIZAÇÃO ASSISTIDA DO ALVÉOLO E PRESERVAÇÃO DO REBORDO ALVEOLAR 25

2.2.1 OPÇÕES PARA MINIMIZAR AS ALTERAÇÕES DIMENSIONAIS ALVEOLARES. .25

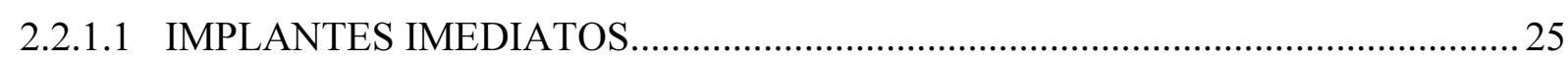

2.2.1.2 PREENCHIMENTO DO ALVÉOLO COM BIOMATERIAIS..................................26

2.2.1.3 ENXERTO GENGIVAL LIVRE ASSOCIADO AO

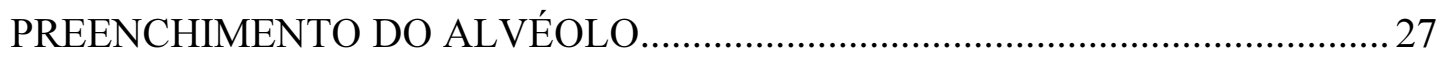

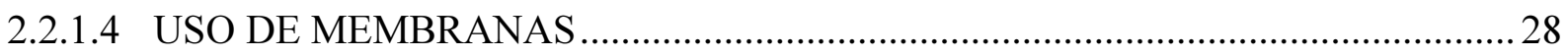

2.2.1.5 EXODONTIA MINIMAMENTE TRAUMÁTICA ……………………………......28

3 PROPOSIÇÃ̃o .31

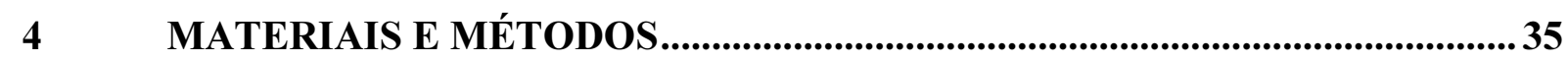

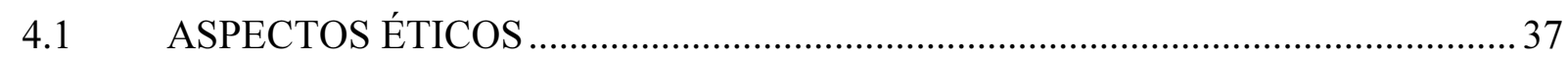

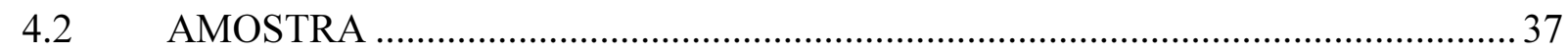

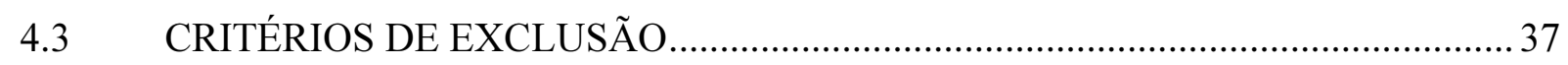

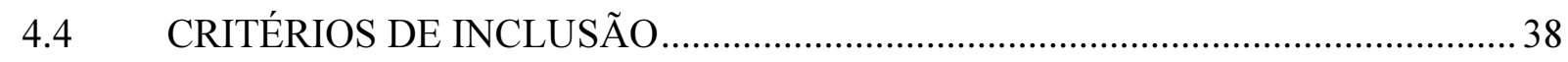

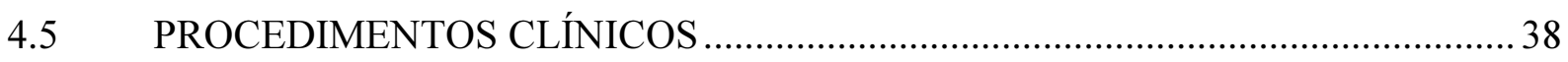

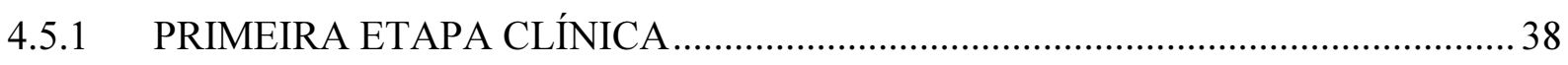

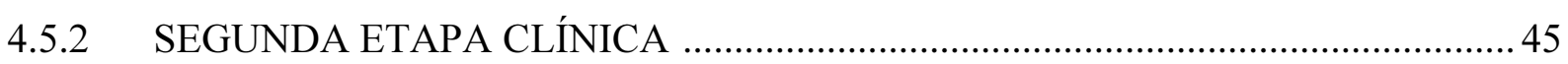

4.6 ANÁLISE DAS ALTERAÇÕES DO REBORDO ALVEOLAR

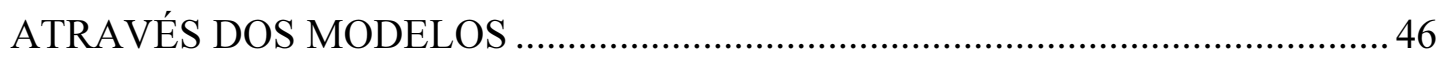

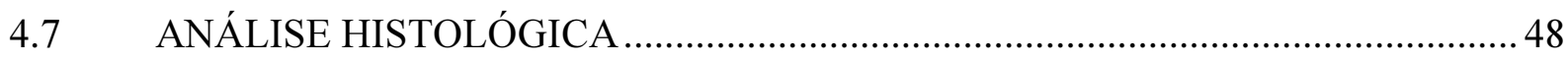





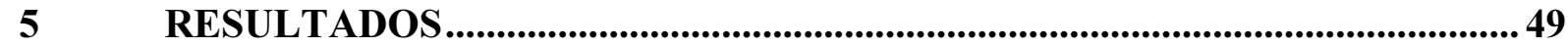

5.1 PROCEDIMENTO DE EXTRAÇÃO DAS RAÍZES RESIDUAIS............................51

5.2 ALTERAÇÕES NO REBORDO ALVEOLAR APÓS 4 MESES ..............................53

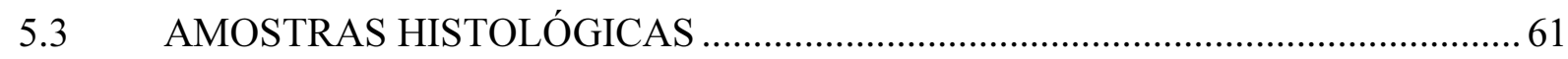

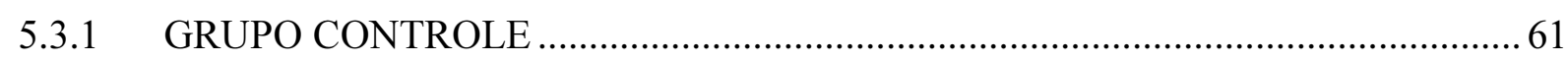

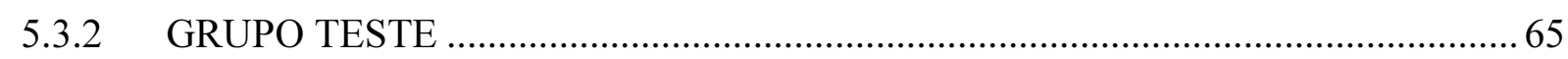

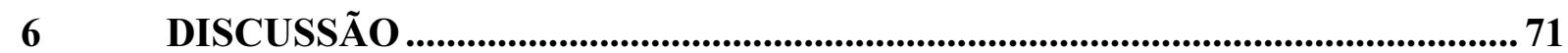

6.1 EXODONTIA MINIMAMENTE TRAUMÁTICA ……………………………..... 73

6.2 ALTERAÇÕES NO REBORDO ALVEOLAR PÓS- EXODONTIA ……………....75

6.3 ANÁLISE DAS AMOSTRAS HISTOLÓGICAS ....................................................79

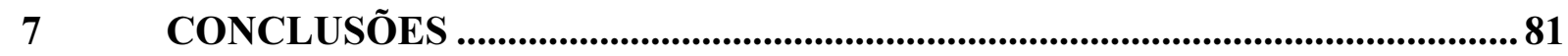

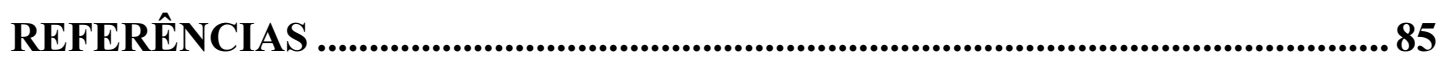

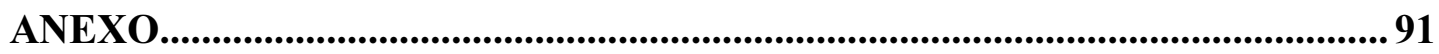



1 INTRODUÇÃO 



\section{INTRODUÇÃO}

Nesta última década, a estética tem recebido maior ênfase no plano de tratamento odontológico, e quando o profissional tem em mente a qualidade de uma reabilitação protética, deve-se considerar a reabsorção do osso alveolar e as transformações tridimensionais que ocorrem após a exodontia. As mudanças que ocorrem no rebordo alveolar são especialmente preocupantes quando envolvem áreas de dentes anteriores, visto que a instalação de um implante dentário em posição ideal é de vital importância para a obtenção de uma reabilitação estética e funcional, e que necessita simular a naturalidade dos dentes através de uma prótese (Lambert et al., 2012).

A extração dentária ainda é um procedimento muito comum nos consultórios odontológicos, sendo praticada rotineiramente sob a justificativa de diversos fatores que levam à sua indicação, como em casos de dentes com suporte periodontal insuficiente, lesões cariosas extensas que inviabilizam restaurações, fraturas radiculares, problemas endodônticos sem resolução e indicação ortodôntica (Irinakis, 2006).

Após a exodontia, a cicatrização natural do alvéolo dentário resulta em uma remodelação que leva a alterações verticais e horizontais do rebordo alveolar, que acometem tanto os tecido duros quanto moles. A reabsorção óssea horizontal pode resultar em uma perda de até 50\% da porção vestibular do osso alveolar (Schropp et al., 2003), reduzindo a espessura total da crista óssea para valores próximos a 3,8 mm (Van der Weijden et al., 2009; Tan et al., 2012). Um colapso dos tecidos moles e uma visível redução volumétrica também são características típicas do rebordo alveolar após as exodontias, e podem também estar relacionados à perda de função do osso alveolar (Araujo e Lindhe, 2005).

Dois terços das alterações teciduais do rebordo alveolar após exodontia ocorrem nos 3 meses iniciais, chegando à perda de $50 \%$ da espessura total do rebordo (cerca de $5-7 \mathrm{~mm}$ ) no período de 12 meses. Alterações mínimas ocorrem na espessura da mucosa e na profundidade de sondagem de dentes vizinhos aos sítios de extração, sendo que a saúde periodontal destes dentes pode melhorar durante o período de cicatrização do alvéolo (Van der Weijden et al., 2009). 
A reabsorção de parte do rebordo pode comprometer a estética e função de futuras próteses convencionais ou implantossuportadas na área, pois a instalação de um implante dentário em posição ideal torna-se mais difícil, criando um desafio a ser vencido pela equipe odontológica, que sempre busca uma restauração protética compatível com os dentes naturais adjacentes (Schropp et al., 2003; Lambert et al., 2012; Tan et al., 2012).

A busca por técnicas que diminuam as transformações do rebordo após a exodontia é o motivo de milhares de estudos no meio científico odontológico. Até o momento, não existe um consenso geral sobre qual o melhor material e a melhor técnica de preservação de rebordo alveolar após exodontia. 
2 REVISÃO DA LITERATURA 



\section{REVISÃO DA LITERATURA}

\subsection{CICATRIZAÇÃO NATURAL DO ALVÉOLO APÓS EXODONTIA}

Vários autores relataram, tanto em animais como em humanos, as simultâneas alterações morfológicas e dimensionais que ocorrem no alvéolo dentário após uma exodontia.

Cardaropoli et al. (2003) investigaram os eventos envolvidos na cicatrização de alvéolos dentários, utilizando 9 cães da raça beagle. Os animais foram sacrificados nos períodos de 1, 3, 7, 14, 30, 60, 90, 120 e 180 dias após a exodontia da raiz distal do quarto pré-molar. Após avaliação histológica das amostras obtidas dos alvéolos, os autores relataram a cronologia dos eventos ocorridos: nos 3 primeiros dias de cicatrização, um coágulo estava ocupando a maior parte do alvéolo; após 7 dias, o coágulo foi parcialmente substituído por um tecido de granulação e após 14 dias, a parte marginal do alvéolo já estava coberta por um tecido conjuntivo rico em vasos e células inflamatórias, principalmente neutrófilos e, foi possível observar a formação de novo tecido ósseo, rico em células; com 30 dias, cerca de $80 \%$ do alvéolo já estava preenchido com uma matriz óssea desorganizada e foi possível observar a presença de osteoclastos ativos nas paredes laterais do alvéolo, indicando o início da remodelação do rebordo; após 60 e 90 dias, uma nova camada de osso foi encontrada separando o tecido gengival marginal do interior do alvéolo e após 120 e 180 dias, esse osso estava mais mineralizado, formando a cortical superior do alvéolo.

Schropp et al. (2003) avaliaram a cicatrização do alvéolo dentário e as transformações morfológicas ocorridas após exodontias, em humanos. As alterações teciduais ao redor de dentes extraídos de 46 pacientes foram mensuradas por um período de 12 meses através de modelos de estudo, radiografias periapicais e radiografias de subtração. Entre os resultados encontrados, os autores relataram a perda evidente em espessura do rebordo alveolar, com diminuição da largura do mesmo em aproximadamente 50\% da espessura inicial (cerca de 5-7 $\mathrm{mm}$ ), sendo que $2 / 3$ destas alterações ocorreram nos 3 primeiros meses de cicatrização. Alterações mínimas ocorreram na espessura da mucosa e na altura do rebordo, ficando restritas a uma pequena diminuição na lingual e um mínimo aumento na vestibular, com medidas inferiores a $1 \mathrm{~mm}$ de diferença. Pequenas alterações também ocorreram na profundidade de sondagem de dentes vizinhos aos sítios de extração, sugerindo que a saúde 
periodontal destes dentes pode melhorar durante o período de cicatrização do rebordo alveolar.

Araújo e Lindhe (2005) investigaram as alterações do rebordo alveolar após exodontia em 12 cães. Os animais foram sacrificados em 1, 2, 4 e 8 semanas após a exodontia da raiz distal do quarto pré-molar. Neste intervalo, foi possível identificar inicialmente a presença de osteoclastos na porção cervical da tábua óssea vestibular dos alvéolos, o que poderia indicar a reabsorção do osso fasciculado que perde sua função após a exodontia e explicar a perda inicial de altura na parede vestibular. Em uma segunda etapa, os autores observaram a ação dos osteoclastos localizados sobre as paredes alveolares externas, reabsorvendo o osso de fora para dentro do alvéolo, resultando em uma diminuição no sentido horizontal. Assim, os autores concluíram que a reabsorção das paredes laterais do alvéolo dentário ocorrem em duas etapas simultâneas: na primeira etapa, o osso antigo é reabsorvido e substituído por uma nova matriz óssea, resultando em uma acentuada redução das paredes ósseas em altura. Na segunda etapa, ocorre a reabsorção do osso das superfícies das paredes laterais em direção ao centro do alvéolo, proporcionado uma diminuição em espessura.

Van der Weijden et al. (2009), em uma revisão sistemática da literatura, investigaram as alterações dimensionais de alvéolos dentários humanos, após a exodontia de elementos dentários. Os resultados mostraram que perdas em altura (de 1,5 a $2 \mathrm{~mm}$ ) e em espessura (média de $3.8 \mathrm{~mm}$ ) podem ser esperadas. Os autores também relataram uma maior perda óssea em altura em pacientes fumantes (cerca de $0.5 \mathrm{~mm}$ a mais) e melhor cicatrização em pacientes que utilizaram soluções tópicas de clorexidina nas primeiras quatro semanas após o procedimento cirúrgico.

Segundo Pagni et al. (2012), minutos após a retirada de um dente, um coágulo sanguíneo preenche o alvéolo dentário e, após uma semana, ele é substituído por tecido de granulação. Em seguida, há a migração de células epiteliais do epitélio marginal em direção ao centro cervical do alvéolo, selando o mesmo e isolando o alvéolo do ambiente bucal externo. O tecido de granulação ao redor das paredes laterais e apicais do alvéolo é gradativamente substituído por uma matriz óssea desorganizada. Do mesmo modo, essa matriz é substituída por osso primário e osso lamelar maduro. Todo o processo dura em média 8 semanas em cães e 14 a 15 semanas em humanos. 
O real motivo para a remodelação que ocorre no alvéolo após a exodontia ainda não é conhecido. Porém, sabe-se que atrofia por desuso, diminuição da vascularização sanguínea e a inflamação local tem grande papel neste complexo processo, que envolve fatores estruturais, funcionais e fisiológicos. Além disso, o microtrauma local causado no momento da exodontia pode acelerar essas alterações (Pagni et al., 2012).

\subsection{ASPECTOS IMPORTANTES DA CICATRIZAÇÃO ASSISTIDA DO ALVÉOLO E PRESERVAÇÃO DO REBORDO ALVEOLAR}

Para reduzir as alterações do rebordo após a exodontia, diferentes tratamentos já foram propostos, como a instalação de implantes em alvéolos frescos (Paolantonio et al., 2001), uso de biomateriais e/ou o uso de membranas (Lekovic et al., 1998; Cardaropolli et al., 2005), uso de substitutos ósseos associados a enxerto gengival livre (Jung et al., 2004), dentre outros, porém os resultados desses estudos mostraram que esses procedimentos não evitam o processo biológico da remodelação óssea alveolar, entretanto elas podem minimizar as alterações dimensionais sofridas pelo rebordo (Fickl et al., 2008a; Fickl et al., 2008b).

\subsubsection{OPÇÕES PARA MINIMIZAR AS ALTERAÇÕES DIMENSIONAIS}

\section{ALVEOLARES}

\subsubsection{IMPLANTES IMEDIATOS.}

A instalação imediata de implantes em alvéolos de extração não é, por si só, capaz de impedir as alterações morfológicas do rebordo alveolar, por não impedir o processo de reabsorção óssea (Araújo et al., 2005) e quando um "gap" maior que 2mm encontra-se presente entre o implante e as paredes ósseas do alvéolo, o preenchimento por osso não se completa, ocorrendo uma maior reabsorção no sentido horizontal do osso alveolar (Botticelli et al., 2013). Dessa forma, sugere-se a incorporação de biomateriais nos espaços alveolares a fim de diminuir a reabsorção do rebordo.

É necessário salientar que, quando o clínico se depara com implantes imediatos, muitas vezes há a tendência de se preencher o espaço no interior do alvéolo com um implante de maior diâmetro ou vestibularizando sua posição. Entretanto, a literatura não sustenta essas 
estratégias, e sim o preenchimento desse espaço, entre alvéolo e implante, com substitutos ósseos. Recessões na face vestibular podem ocorrer após a instalação imediata de implantes, e múltiplos fatores podem contribuir para este evento: o mal posicionamento do implante, parede óssea vestibular fina ou perda de sua integridade e pacientes com biótipo periodontal fino. A instalação de coroas provisórias imediatas pode diminuir o risco do aparecimento dessas recessões, por ajudar a manter o nível da margem gengival e preservar a arquitetura dos tecidos moles na área da exodontia (Chen e Buser, 2009; Cosyn et al., 2012; Fiamengui Filho et al., 2014a).

\subsubsection{PREENCHIMENTO DO ALVÉOLO COM BIOMATERIAIS.}

Biomaterial é qualquer substância construída de tal forma que, sozinha ou como parte de um sistema complexo, é usada para dirigir, pelo controle de interações com componentes de um sistema vivo, o curso de um procedimento diagnóstico ou terapêutico, quer seja em humanos ou animais (de Carvalho et al., 2010). Um biomaterial ideal para enxerto em alvéolo deveria prevenir a redução de volume do rebordo que ocorre após a extração (Lekovic et al., 1998; Schropp et al., 2003) e permanecer no local até que a formação de osso ocorra de maneira suficiente. Os substitutos ósseos devem estimular a osteogênese e servir de arcabouço para que o osso se forme.

Estudos mostram que a utilização de enxerto ósseo inorgânico em alvéolos de extração, é significativamente eficaz na formação óssea, com diminuição na porcentagem do processo de reabsorção óssea alveolar (menos de 20\%), quando se compara com alvéolos nos quais nenhum biomaterial foi utilizado. Após 3 meses, é notável a presença de partículas do biomaterial envoltas por osso neoformado, demonstrando que o biomaterial serve de arcabouço para formação de novo osso (Cardaropoli et al., 2005; Nevins et al., 2006).

Entretanto, Lindhe et al. (2013) verificaram que em alvéolos preenchidos somente pelo coágulo, há uma formação de matriz óssea cinco vezes maior do que quando preenchidos por um biomaterial inorgânico. Porém, há a formação de uma nova cortical óssea na margem superior do alvéolo e, uma pequena depressão pode ser notada mais para o centro do alvéolo, no sentido apical, proporcionando uma perda em altura nessa região. Já com o uso do osso bovino inorgânico, essa nova cortical não foi formada e essa depressão no centro do alvéolo não foi notada. Assim, os autores concluíram que, apesar da diferença na quantidade de nova 
matriz óssea formada, o uso do biomaterial ajudou na diminuição da remodelação do alvéolo, o que pode ser explicado pela reabsorção lenta do material utilizado.

Um biomaterial processado de origem xenógena (Osso bovino integral, Orthogen ${ }^{\circledR}$, Baumer, Brasil) foi analisado microscopicamente por Gália et al (2011). Neste estudo, os autores verificaram que o biomaterial apresentava estrutura típica de osso medular e com poros interconectados, comprovando que o processamento deste biomaterial não alterou sua estrutura tridimensional inicial, característica necessária para a formação de novo osso ao redor e no interior das partículas do biomaterial. Assim, os autores concluíram que esse biometarial tem características similares à outros produtos vendidos amplamente no mercado para regeneração óssea guiada ou preenchimento alveolar.

\subsubsection{ENXERTO GENGIVAL LIVRE ASSOCIADO AO PREENCHIMENTO} DO ALVÉOLO

Técnicas de selamento do alvéolo após exodontia foram desenvolvidas na tentativa de limitar as alterações sofridas pelo rebordo alveolar.

A técnica conhecido como "soft tissue punch" consiste no preenchimento do alvéolo com um substituto ósseo e selamento deste com um enxerto gengival livre. Para garantir a eficiência do procedimento, o dente deve ser extraído com o menor trauma possível e o tecido gengival da área receptora deve ser preservado e as bordas desepitelizadas. Após o preenchimento do alvéolo com um substituto ósseo, as suturas devem ser realizadas com fios delicados, garantindo a perfeita estabilização do enxerto gengival no leito receptor para que o tecido enxertado sobreviva. Os autores propuseram que estabilizando a arquitetura gengival com o enxerto gengival livre poderia haver um menor colapso dos tecidos moles, aliada à vantagem da técnica em proporcionar a cicatrização do alvéolo por primeira intenção sem prejudicar a estética do rebordo e da papila gengival (Jung et al., 2004).

Uma diminuição da remodelação do rebordo ocorre quando combinados o uso do osso bovino desproteinado e enxerto gengival livre para selar o alvéolo, pois esse vedamento do alvéolo dentário após extração ajuda a diminuir as alterações externas do rebordo alveolar (Fickl et al., 2008a; Fickl et al., 2008b). 


\subsubsection{USO DE MEMBRANAS}

A utilização de membranas reabsorvíveis está indicada para a preservação do rebordo alveolar, após a exodontia, prevenindo defeitos, por permitir menor perda óssea horizontal, vertical e melhor cicatrização interna do alvéolo (Lekovic et al., 1998). Entretanto, o uso de membranas como barreiras oclusivas possui desvantagens como: necessidade de elevação de retalhos vestibulares e linguais para sua acomodação; deslocamento do retalho para coronal e conseqüente deslocamento da linha mucogengival; diminuição de profundidade do vestíbulo; diminuição da quantidade de mucosa ceratinizada por vestibular. Além disso, há o risco de exposição da membrana e conseqüente infecção bacteriana (Simion et al., 1994).

Nos casos de regeneração óssea guiada (ROG) em alvéolos, a utilização de membranas reabsorvíveis tem o intuito de formar uma barreira física, impedindo a penetração de células epiteliais para dentro dos alvéolos. Desse modo, ajuda a estabilizar, durante as fases iniciais do período de cicatrização, as partículas do substituto ósseo colocadas no sítio, promovendo uma maior quantidade de novo osso formado para a preservação alveolar (Hämmerle et al., 2008; Perelman-Jarmon et al., 2012).

\subsubsection{EXODONTIA MINIMAMENTE TRAUMÁTICA}

A exodontia minimamente traumática tem sido citada como necessária em vários estudos (Yalcin et al., 2009; Dym e Weiss, 2012; Muska et al., 2013), sendo de fundamental importância para a obtenção de boa estabilidade inicial em caso de implantes imediatos, bom prognóstico em longo prazo ou preservação do alvéolo para futura reabilitação. Porém, muitas vezes, no momento da exodontia, existe uma grande dificuldade em preservar a tábua óssea vestibular, geralmente de espessura muito fina, com médias de espessura de 0,8 $\mathrm{mm}$ em dentes anteriores e 1,1 mm em pré-molares (Huynh-Ba et al., 2010). Dentre as técnicas relatadas na literatura, pode-se citar o uso de brocas helicoidais para o desgaste interno da raiz (Yalcin et al., 2009) e dispositivos que usam o canal radicular como ancoragem para a exodontia (Muska et al., 2013; Fiamengui Filho et al., 2014b).

Outros aspectos cirúrgicos como a elevação de um retalho total no momento da exodontia também podem influenciar de maneira negativa a preservação do rebordo alveolar. Um estudo com cães demonstrou que a elevação do retalho resulta em uma perda mais acentuada da espessura do rebordo quando comparada às exodontias realizadas sem retalho. 
Esse processo ocorre, supostamente, em virtude da separação do periósteo e a ruptura de sua inserção de tecido conjuntivo junto à superfície óssea, com conseqüente diminuição de suprimento sanguíneo. Esse fato poderia causar a morte dos osteócitos e necrose do tecido superficial mineralizado das paredes ósseas, ativando os osteoclastos do periósteo reposicionado e causando reabsorção superficial deste osso (Fickl et al., 2008a, Fickl et al., 2008b). O comportamento do paciente no período pós-operatório e aspectos morfológicos do sítio cirúrgico também podem influenciar o reparo pós exodontia (Muska et al., 2013). 

3 PROPOSIÇÃ̃ 



\section{PROPOSIÇÃO}

O presente estudo tem como objetivos primários:

- Avaliar clinicamente o comportamento do biomaterial Orthogen ${ }^{\circledR}$ na preservação das dimensões do rebordo alveolar pós-exodontia

- Descrever histologicamente as características encontradas nos alvéolos enxertados após 4 meses de reparo

Como objetivos secundários, o estudo irá:

- Comparar as mudanças dimensionais nos rebordos alveolares tratados ou não com o biomaterial Orthogen $\mathbb{R}$

- Avaliar a eficácia do Kit para Extração Atraumática Neodent ${ }^{\circledR}$ na exodontia de raízes residuais de dentes anteriores superiores 



\section{Materiais e Métodos}





\section{MATERIAIS E MÉTODOS}

\subsection{ASPECTOS ÉTICOS}

O projeto de pesquisa foi aprovado pelo Comitê de Ética e Pesquisa e inscrito na Plataforma Brasil com o número protocolar CAAE: 03016412.7.0000.5417. O parecer é aprovação é de número 48497.

Os indivíduos selecionados para esse estudo clínico prospectivo receberam informações esclarecedoras sobre o estudo e o Termo de Consentimento Livre e Esclarecido foi assinado por eles antes do inicio do início dos procedimentos clínicos (Declaração de Helsinki 2000). Os pacientes foram selecionados e tratados no período de outubro de 2012 e setembro de 2013.

\subsection{AMOSTRA}

A amostra foi constituída por 20 pacientes, 13 mulheres e 7 homens, com idades entre 25 e 56 anos, com necessidade de exodontia de uma raiz residual na maxila (com exceção dos molares) e indicação de reabilitação com um implante dentário. Os motivos das perdas dentarias incluíram fraturas radiculares, falhas no tratamento endodôntico e lesões de cáries extensas, sem possibilidade de restauração ou tratamento protético.

\subsection{CRITÉRIOS DE EXCLUSÃO}

Foram excluídos da pesquisa os indivíduos com as seguintes características:

- Menores de 18 anos de idade

- Presença de doença periodontal

- Fumantes

- Presença de doenças sistêmicas ou auto imunes

- Mulheres grávidas ou lactantes

- Quimioterapia / Radioterapia nos últimos 5 anos 


\subsection{CRITÉRIOS DE INCLUSÃO}

Foram incluídos na amostra pacientes com dentes com necessidade de exodontia e que possuíam as paredes ósseas alveolares preservadas. Esse requisito foi verificado após a exodontia de cada dente, através do uso de um instrumento explorador para detectar possíveis fenestrações ósseas nas paredes alveolares. Todas as áreas apresentavam um mínimo de $2 \mathrm{~mm}$ de mucosa ceratinizada ao redor dos dentes.

Todos os pacientes receberam instruções de higiene oral, raspagem, alisamento radicular e profilaxia boca toda antes do início dos procedimentos clínicos deste estudo.

Os pacientes avaliados e que não puderam ser incluídos na amostra deste estudo foram encaminhados para o setor de triagem da Faculdade de Odontologia de Bauru para que recebessem o tratamento adequado para cada caso.

\subsection{PROCEDIMENTOS CLÍNICOS}

\subsubsection{PRIMEIRA ETAPA CLÍNICA}

Antes do procedimento de exodontia do dente selecionado para o estudo, a arcada superior do paciente foi moldada, através da técnica de um passo, utilizando moldeiras de plástico e sicolona de condensação leve e pesada (Optosil/Xantopren ${ }^{\circledR}$, Heraeus Kulzer GmBH, Hanau, Alemanha). Através da moldagem, foi confeccionado um modelo de gesso, utilizando gesso especial tipo IV.

Após anestesia local com articaína a 4\% com adrenalina 1:100.000 (Articaine ${ }^{\circledR}-$ Dfl Indústria e Comércio Ltda, Rio de Janeiro-RJ, Brasil), foi realizada incisão intrasulcular com lâmina de bisturi 15c e delicada desinserção das fibras gengivais ao redor da raíz remanescente utilizando um periótomo. Para a remoção da raiz, foi realizado o preparo do canal radicular com brocas helicoidais de 1.1 e $1.5 \mathrm{~mm}$, o que possibilitou a inserção do dispositivo tracionador no conduto radicular preparado, à partir do qual um cabo de aço foi adaptado e inserido no extrator dentário, iniciando o processo de exodontia, que ocorre no sentido do longo eixo da raiz residual (Kit De Extração Atraumática Neodent ${ }^{\circledR}$, BRASIL). Os procedimentos foram realizados sem a abertura de retalho ou comprometimento da gengival 
marginal, com a intenção de preservar ao máximo os tecidos duros e moles ao redor do alvéolo.

Através de uma lista aleatória realizada no programa Excell (Microsoft ${ }^{\circledR}$, USA), os pacientes foram divididos em dois grupos: Grupo 1 / Teste (T) e Grupo 2 / Controle (C). Dessa maneira, após a exodontia, os alvéolos dentários receberam as seguintes abordagens:

- Grupo 1 / Teste (T): Nos casos incluídos no grupo teste, a parte interna da margem gengival foi deseptelizada com a lâmina de bisturi 15 c, expondo tecido conjuntivo. $\mathrm{O}$ alvéolo foi preenchido até o limite da crista óssea com um biomaterial de origem xenógena (Osso bovino integral, Orthogen $\AA$, Baumer, Brasil) hidratado com soro fisiológico. O selamento do alvéolo foi realizado com um Enxerto Gengival Livre (EGL), com espessura média de $2 \mathrm{~mm}$, proveniente do palato e suturado com fio reabsorvível VICRYL ${ }^{\mathrm{TM}}$ 4.0, na gengival marginal do alvéolo, com pontos simples. Os procedimentos realizados neste grupo estão ilustrados na figura 1.

- Grupo 2 / Controle (C): Nos casos incluídos no grupo controle, também a parte interna da margem gengival foi deseptelizada com uma lâmina de bisturi $15 \mathrm{c}$, expondo tecido conjuntivo e o selamento do alvéolo foi realizado com um Enxerto Gengival Livre (EGL), com espessura média de $2 \mathrm{~mm}$, proveniente do palato e suturado com fio reabsorvível VICRYL ${ }^{\mathrm{TM}}$ 4.0, na gengival marginal do alvéolo, com pontos simples, sem a inclusão de nenhum tipo de biometarial para preencher o alvéolo, sendo esse preenchido apenas por coágulo sanguíneo. Os procedimentos realizados neste grupo estão ilustrados na figura 2.

Todas os procedimentos cirúrgicos foram realizados por um único cirurgião dentista com experiência nos procedimentos já citados.

Os pacientes foram medicados com amoxilicina 500mg, de $8 \mathrm{em} 8$ horas, por 7 dias e nimesulime 100mg, de 12 em 12 horas, por 3 dias.

Como auxiliar na manutenção da higiene oral, os pacientes foram instruídos a bochechar clorexidina $0,12 \%$ duas vezes ao dia, durante as 2 primeiras semanas. Após 7 dias, uma nova consulta foi realizada para controle e, após 14 dias, os pontos remanescentes foram retirados. Nenhum outro tipo de procedimento foi realizado nos pacientes durante o período de cicatrização e espera para instalação do implante, que durou 4 meses. 


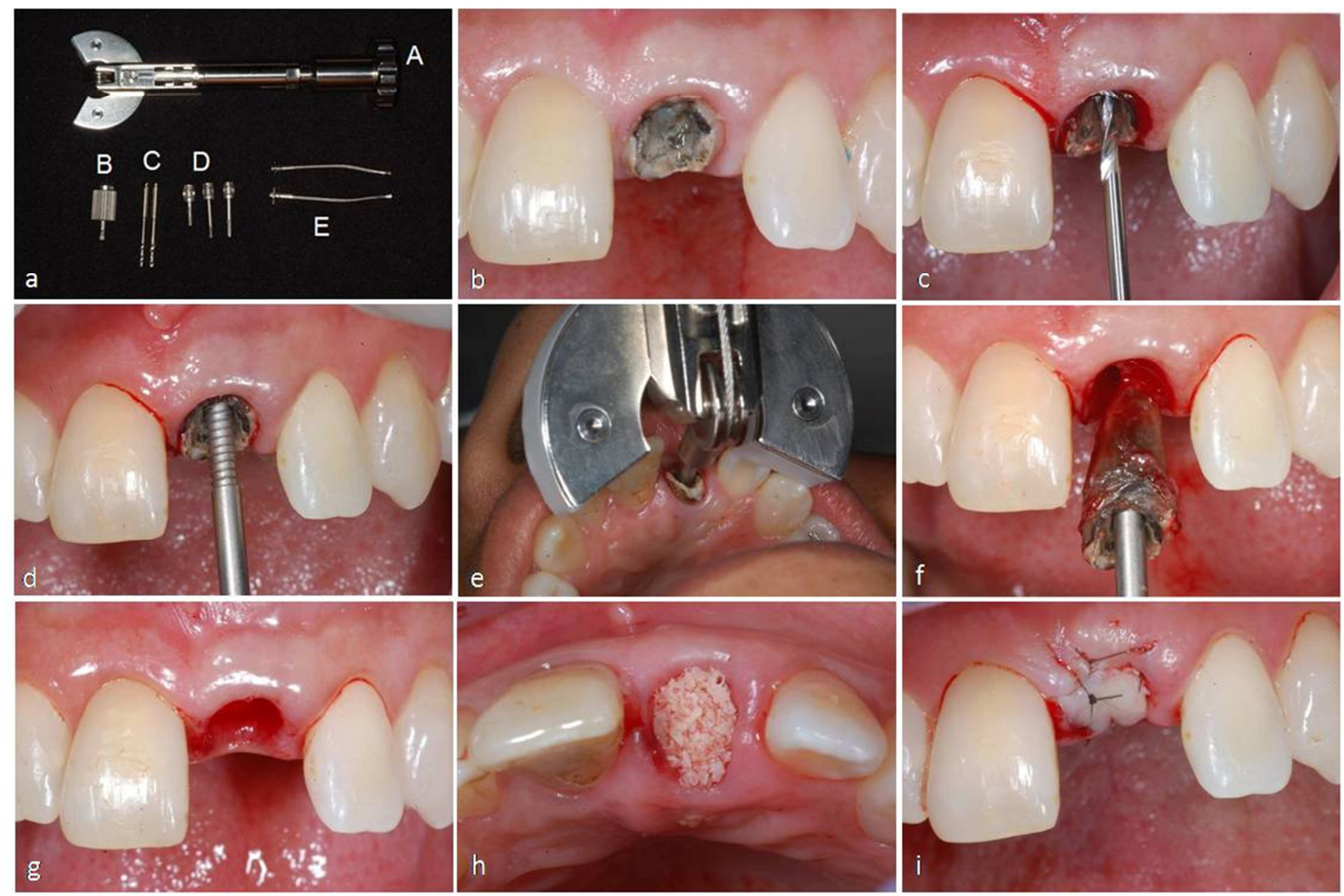

Figura 1. Procedimento de exodontia minimamente traumática e preenchimento do alvéolo com biomaterial realizado nos pacientes do Grupo 1 / Teste. a) componentes do kit de extração atraumática Neodent. b) Foto frontal inicial contendo remanescente radicular fraturado. c) Preparo do interior da conduto radicular com broca helicoidal de $1.3 \mathrm{~mm}$. d) Inserção do componente de tração no interior do conduto radicular preparado. e) Dispositivo tracionador apoiado nos dentes laterais, pronto para iniciar a exodontia no sentido apico-coronal. f) Raiz sendo extraída pelo tracionamento. g) Alvéolo dentário pós-exodontia. Notar a completa preservação dos tecidos circunjacentes. h) Preenchimento do alvéolo com osso particulado bovino (Orthogen). i) Sutura do EGL proveniente do palato, vedando o alvéolo. 


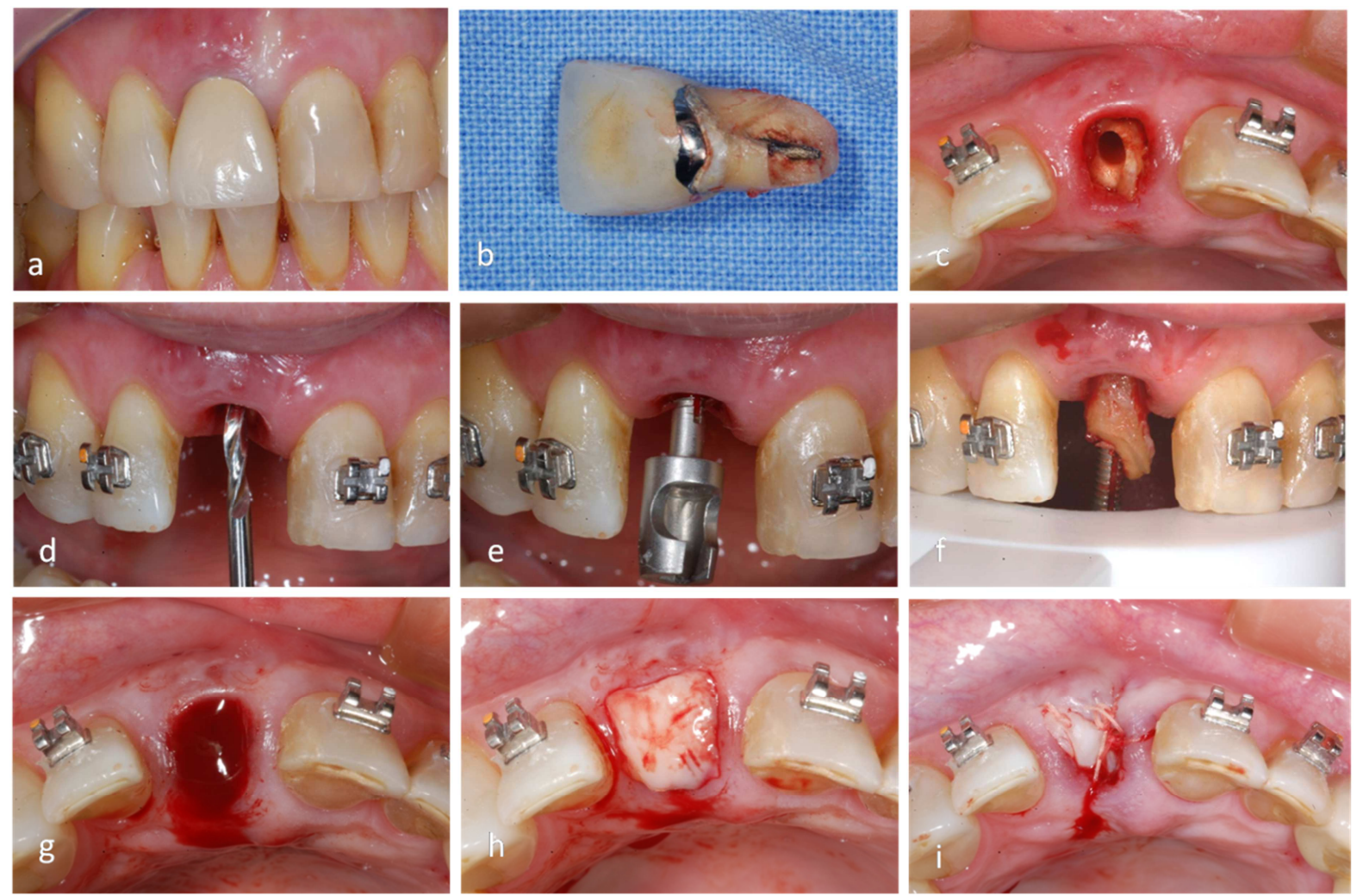

Figura 2. Procedimento de exodontia minimamente traumática e selamento do alvéolo apenas com o enxerto gengival livre, mantendo apenas o coágulo no interior do alvéolo. a) Foto frontal inicial. b) Parte coro-radicular do elemento 11 fraturado. c) Foto clínica do remanescente radicular fraturado. d) Preparo do interior do conduto radicular com broca helicoidal de $1.3 \mathrm{~mm}$. e) Tracionador instalado no interior do canal radicular. f) Momento da exodontia, com o extrator apoiado nos dentes laterais. g) Foto oclusal do alvéolo dentário após a exodontia, mostrando a estabilização de um coágulo sanguíneo no interior do alvéolo. h) EGL posicionado sobre o alvéolo. i) Sutura do EGL proveniente do palato, vedando o alvéolo. 



\subsubsection{SEGUNDA ETAPA CLÍNICA}

Após o período de cicatrização e acompanhamento de 4 meses, nova moldagem da arcada superior foi realizada e um novo modelo de gesso confeccionado.

Neste momento, uma segunda intervenção cirúrgica foi realizada para instalação do implante dentário na área. A escolha do implante adequado para cada área foi realizada através do uso de uma Tomografia Computadorizada obtida no Departamento de Estomatologia da Faculdade de Odontologia de Bauru (Protocolo da Faculdade Odontologia de Bauru, Universidade de São Paulo: 2 Arch $8 \mathrm{~cm}, 20 \mathrm{sec}$, 0,3 Voxel (18,45mAs). Todas as tomografias foram processadas por I-CAT Cone Beam 3-D Dental Imaging System, na Clínica de Radiologia do Departamento de Estomatologia da FOB.

Como parte da preparação do leito para a instalação do implante dentário, uma broca trefina de $3.0 \mathrm{~mm}$ de diâmetro interno foi utilizada para colher amostras de tecido mole e ósseo das áreas que iriam receber o implante. Espécimes de 8-9 $\mathrm{mm}$ de comprimento de gengiva/osso foram obtidos e imediatamente selados em frascos com formalina $10 \%$ e foram para o processamento histotécnico visando análise histológica. Para complementar o preparo do leito para a instalação do implante dentário, foram utilizadas brocas helicoidais de diâmetro $2.0 \mathrm{~mm}$ e $2.8 \mathrm{~mm}$ (Neodent ${ }^{\circledR}$, Brasil), numa profundidade mínima de $11 \mathrm{~mm}$ da crista óssea da parede vestibular do alvéolo, com intenção de instalar implantes com plataforma Morse (Neodent ${ }^{\circledR}$, Brasil) e com o mínimo de $9 \mathrm{~mm}$ de comprimento, ficando posicionados infra-ósseos com aproximadamente $2 \mathrm{~mm}$ abaixo da crista óssea. Coroas provisórias imediatas parafusadas foram instaladas nos casos onde a estabilidade inicial do implante foi maior que $45 \mathrm{~N} / \mathrm{cm} 3$.

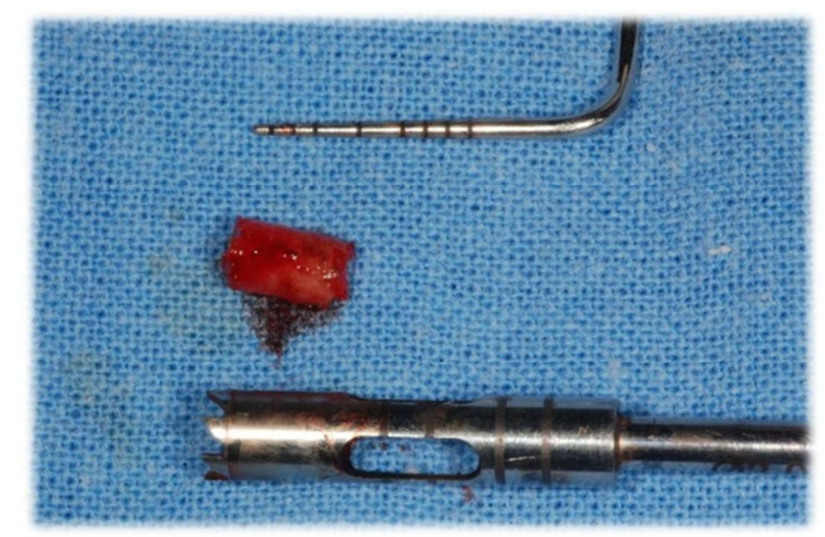

Figura 3. Amostra óssea retirada com broca trefina de $3 \mathrm{~mm}$, do local do alvéolo cicatrizado, momentos antes à instalação do implante dentário no mesmo local. 


\subsection{ANÁLISE DAS ALTERAÇÕES DO REBORDO ALVEOLAR ATRAVÉS DOS MODELOS}

Os modelos de gesso obtidos através das moldagens de ambos os grupos, nos tempos inicial (antes da exodontia) e finais (4 meses de cicatrização e momento da instalação do implante) foram escaneados através do scanner Neoshape (Neodent ${ }^{\circledR}$, Brasil) e imagens tridimensionais foram obtidas. Essas imagens foram analisadas através do programa 3Shape OrthoAnalyzer ${ }^{\mathrm{TM}}$.

Cortes tridimensionais foram realizados e uma imagem transversal de cada modelo foi obtida (figura 5a), possibilitando realizar as medidas para comparação dos dois tempos.

Foram definidas as seguintes medidas:

- espessura do topo do rebordo (figura 5b): Linha perpendicular ao plano oclusal que liga os dois pontos mais altos do rebordo alveolar remanescente

- espessura do centro do rebordo (figura 5c): linha perpendicular ao plano oclusal que liga as faces vestibular e palatina do rebordo alveolar e passa pelo meio do rebordo

- perímetro da área cervical do rebordo (figura 5d): linha que corta a parte superior do rebordo alveolar remanescente, delimitada inferiormente pela linha de espessura do centro do rebordo alveolar remanescente

- área cervical do rebordo (figura 5e): área do rebordo alveolar remanescente que se encontra acima da linha de espessura do centro do rebordo alveolar remanescente

- área total do rebordo (figura 5f):, engloba toda a área do rebordo, delimitada apicalmente por uma linha reta paralela ao plano oclusal que liga a face vestibular e palatina do rebordo remanescente, que se inicia no ponto mais inferior da face vestibular do rebordo e vai de encontro a face palatina

Todas as medidas foram realizadas em 3 momentos distintos, com o mínimo de uma semana de diferença, por um examinador que desconhecia os tratamentos realizados em cada paciente.Uma média 3 medidas foi realizada e foi considerada a medida real, buscando eliminar qualquer subjetividade que possa ocorrer na marcação dos pontos nas imagens geradas no programa Orthoanalyzer ${ }^{\circledR}$. 


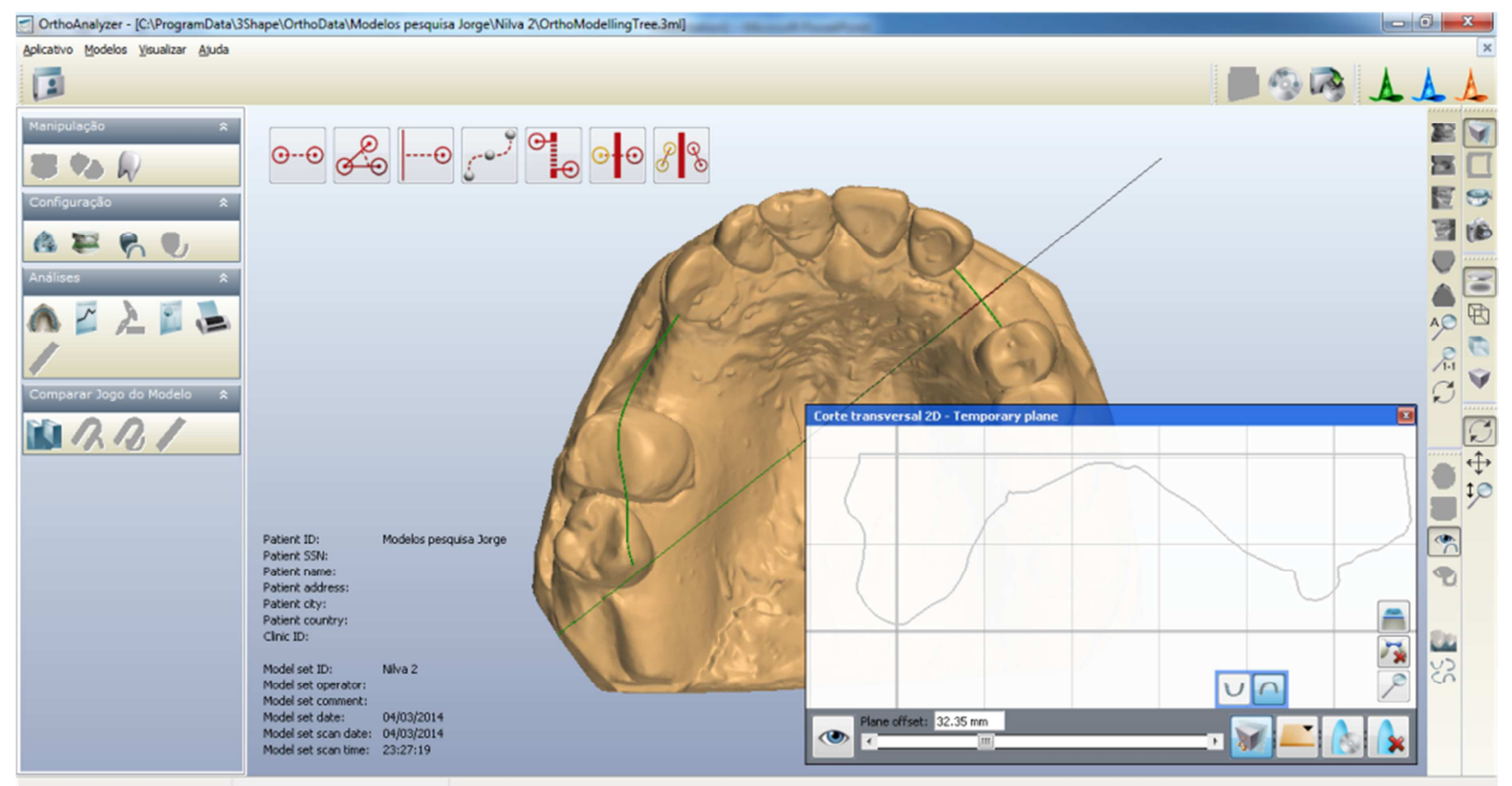

Figura 4 - Imagens do modelo virtual sendo analisado no programa orthoanalyzer. O corte foi realizado no centro do rebordo alveolar desdentado, obtendo uma imagem do rebordo central remanescente.

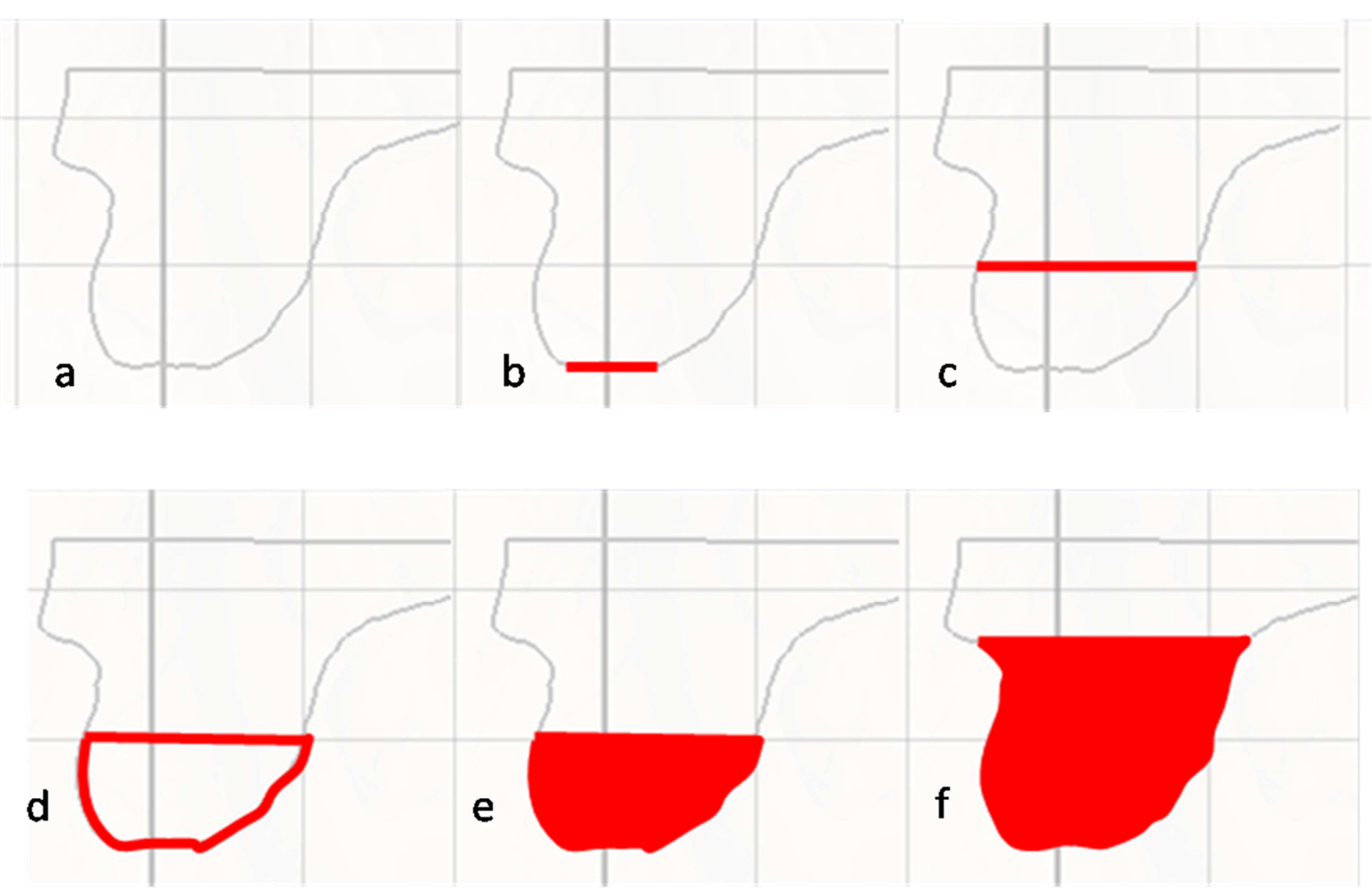

Figura 5. Imagens obtidas dos cortes realizados nos modelos. a) Rebordo alveolar; b) espessura do rebordo; c) espessura do centro do rebordo; d) perímetro da área cervical do rebordo; e) área cervical do rebordo; f) área total do rebordo 


\subsection{ANÁLISE HISTOLÓGICA}

As amostras ósseas imersas em formalina a 10\% foram encaminhadas ao laboratório Histoplus (Araçatuba, São Paulo) para processamento histotécnico. O processamento realizado foi: lavagem das peças em água corrente por 24 horas; descalcificação em ácido nítrico a 10\%; desidratação em álcool absoluto e diafanização em xilol; inclusão em blocos de parafina, confecção de cortes de $4 \mu \mathrm{m}$ de espessura da região central de cada espécime e coloração com HE. A análise microscópica foi realizado por um patologista experiente. 
5 RESULTADOS 



\section{RESULTADOS}

\subsection{PROCEDIMENTO DE EXTRAÇÃO DAS RAÍZES RESIDUAIS}

Foram realizadas durante este tudo 20 exodontias, distribuídos na arcada dentária superior de acordo com o gráfico abaixo:

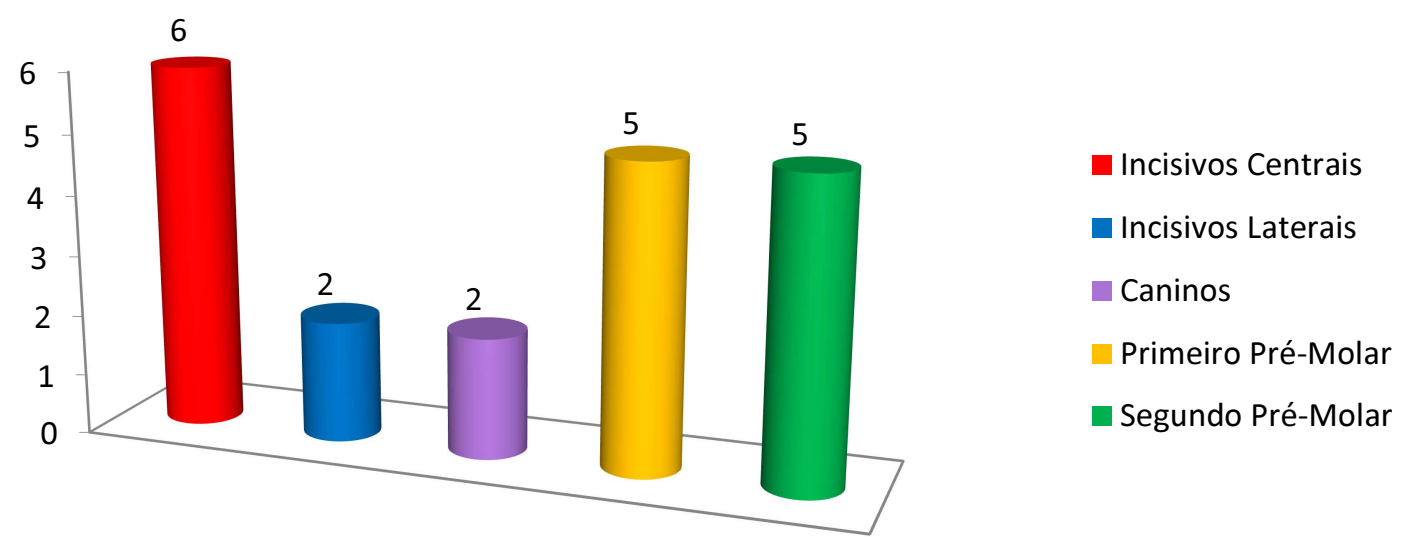

Gráfico 1. Distribuição das raízes residuais extraídas na arcada dentária superior dos pacientes incluídos no estudo.

Durante a retirada das raízes residuais, o total de tempo de duração do procedimento foi monitorado, iniciando-se à partir do início do preparo do conduto radicular, incluindo a instalação do dispositivo tracionador e a exodontia propriamente. Os dados são descritos no gráfico abaixo:

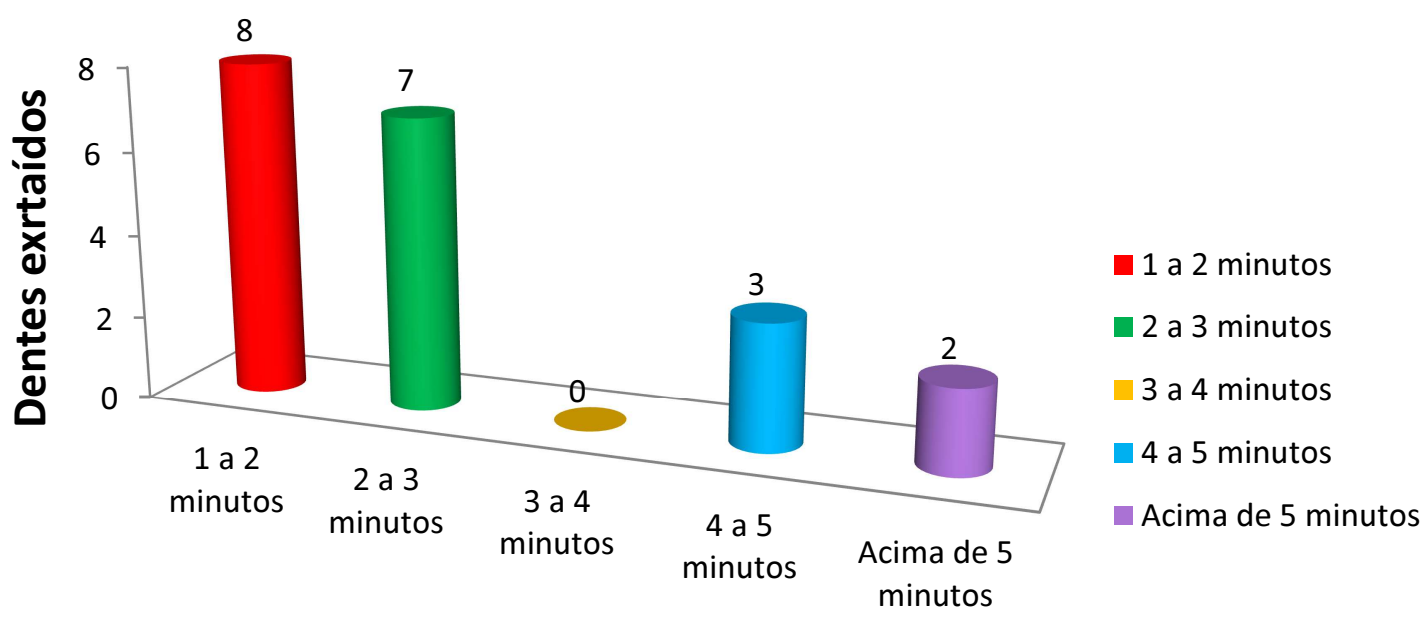

Duração do procedimento de exodontia (minutos)

Gráfico 2. Duração total do tempo de exodontia (em minutos). É possível notar que, em 15 casos, os procedimentos foram concluídos em no máximo 3 minutos. 

Em 2 dos 20 casos, houve uma maior dificuldade durante o procedimento, pois os remanescentes radiculares estavam muito cariados e, por isso, durante a instalação do tracionador, o mesmo soltava-se da raiz no momento da tração. Nestes 2 casos, as raízes não saíram inteiras (figura6)

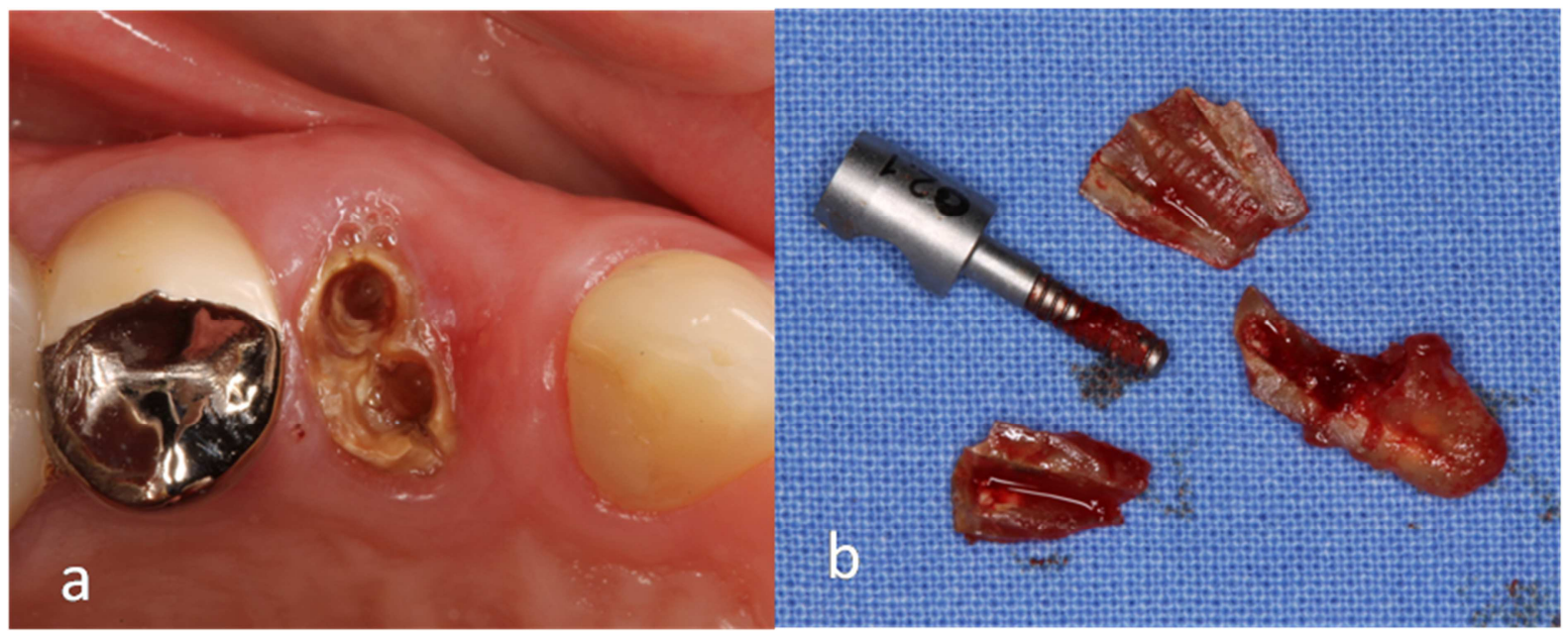

Figura 6. a) Remanescentes radiculares de um primeiro pré-molar superior cariado e com fratura radicular. b) Partes das raízes após a exodontia minimamente traumática

\subsection{ALTERAÇÕES NO REBORDO ALVEOLAR APÓS 4 MESES}

As imagens clínicas que representam de melhor maneira os dois grupos são demonstrada abaixo:
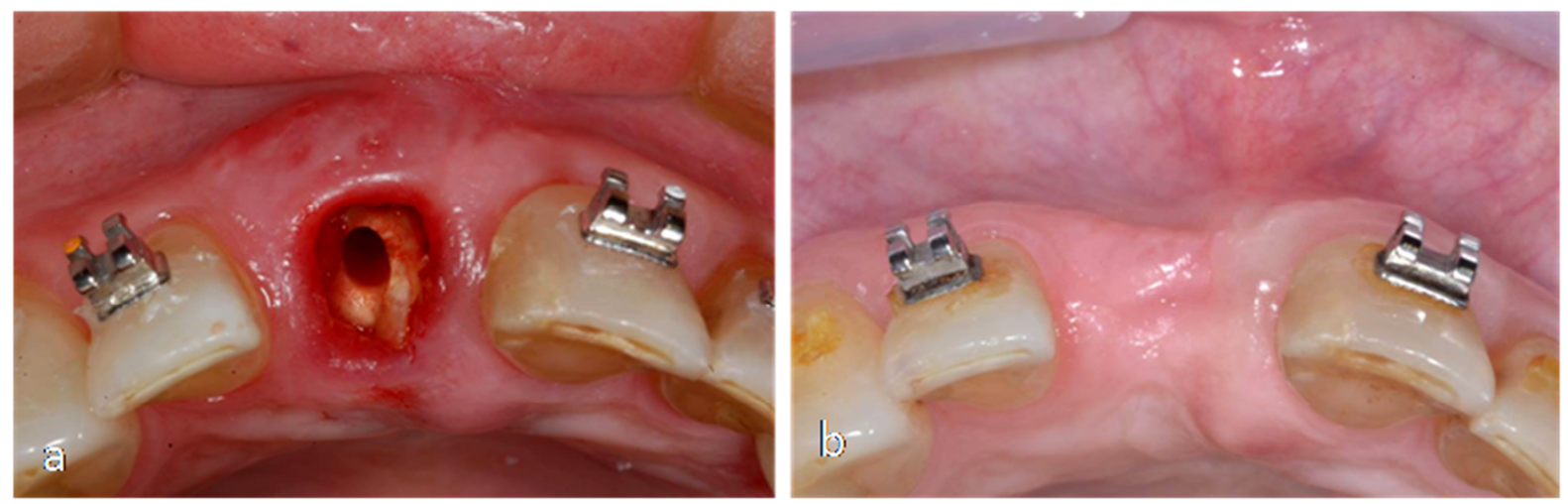

Figura 7. a) Imagem de amostra do grupo controle, mostrando raiz residual do dente 11 antes de ser extraída. b) Rebordo cicatrizado após exodontia minimamente traumática + EGL (Grupo Controle - 4 meses) 


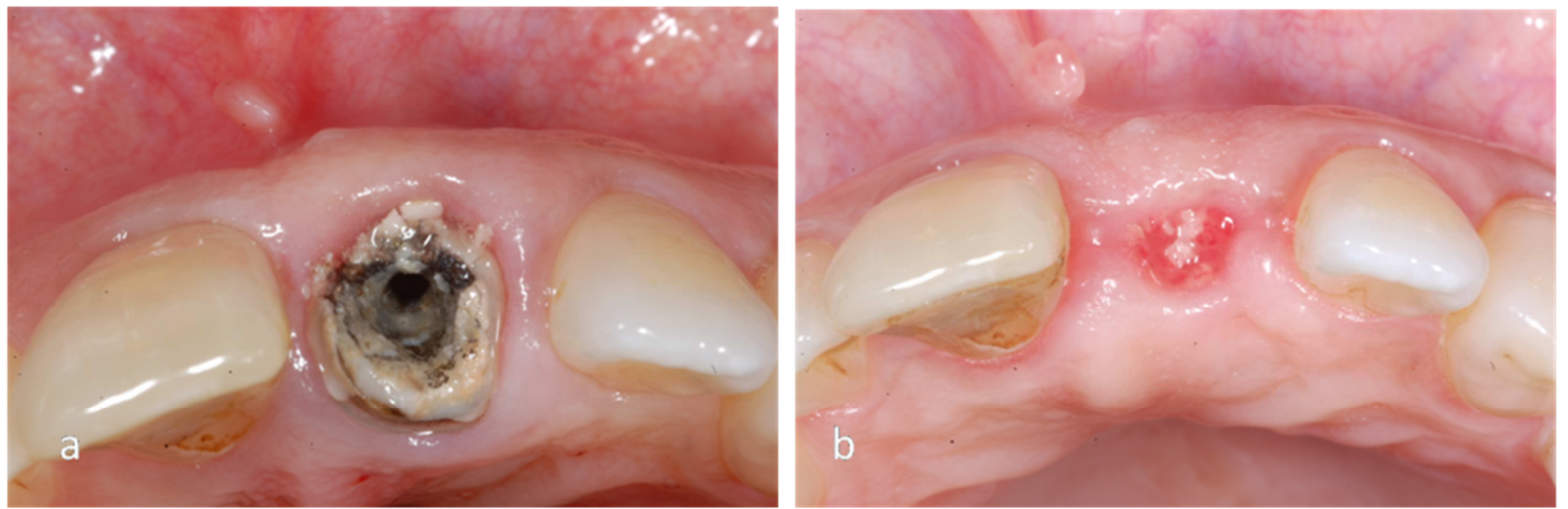

Figura 8. a) Imagem de amostra do grupo teste, mostrando raiz residual do dente 21 antes de ser extraída. b) Rebordo cicatrizado após exodontia minimamente traumática + preenchimento do alvéolo com Ortogen + EGL (Grupo Teste - 4 meses). Notar uma mínima esfoliação de partículas do material enxertado no centro do alvéolo.

A tabela abaixo expõe os dados das medidas realizadas capturadas dos modelos escaneados no momento inicial, após 4 meses de cicatrização, comparando a diferença entre elas no grupo controle.

Tabela 1. Medidas realizadas nos modelos virtuais do grupo controle (coágulo + EGL)

\section{Grupo Coágulo + EGL}

\begin{tabular}{lccccc} 
Rebordo Alveolar & Média Inicial & $\begin{array}{c}\text { Média após 4 } \\
\text { meses }\end{array}$ & $\begin{array}{c}\text { entre as } \\
\text { médias }\end{array}$ & \% de perda & P \\
Espessura Topo & $9,35 \mathrm{~mm}$ & $6,15 \mathrm{~mm}$ & $3,2 \mathrm{~mm}$ & $34,22 \%$ & $*<0,0001$ \\
Espessura Centro & $16,22 \mathrm{~mm}$ & $12,76 \mathrm{~mm}$ & $3,4 \mathrm{~mm}$ & $20,96 \%$ & $* 0,0037$ \\
Perímetro Cervical & $42,22 \mathrm{~mm}$ & $32,28 \mathrm{~mm}$ & $9,94 \mathrm{~mm}$ & $23,54 \%$ & $* 0,0016$ \\
Área Cervical & $71,04 \mathrm{~mm}^{2}$ & $51,3 \mathrm{~mm}^{2}$ & $19,7 \mathrm{~mm}^{2}$ & $27,78 \%$ & $* 0.013$ \\
Área total & $133,8 \mathrm{~mm}^{2}$ & $89,1 \mathrm{~mm}^{2}$ & $44,7 \mathrm{~mm}^{2}$ & $33,40 \%$ & $* 0,0012$ \\
\hline
\end{tabular}

* Diferença estatisticamente significante 

A tabela abaixo expõe os dados das medidas realizadas nos modelos virtuais no momento inicial, após 4 meses de cicatrização, comparando a diferença entre elas no grupo teste.

Tabela 2. Medidas realizadas nos modelos virtuais do grupo teste (Orthogen + EGL)

Grupo Orthogen + EGL

\begin{tabular}{|c|c|c|c|c|c|}
\hline Rebordo Alveolar & $\begin{array}{l}\text { Média } \\
\text { Inicial }\end{array}$ & $\begin{array}{c}\text { Média após } 4 \\
\text { meses }\end{array}$ & $\begin{array}{l}\text { Diferença entre } \\
\text { as médias }\end{array}$ & $\%$ de perda & $\mathbf{P}$ \\
\hline Espessura Topo & $10,05 \mathrm{~mm}$ & $7,89 \mathrm{~mm}$ & $2,16 \mathrm{~mm}$ & $21,49 \%$ & $* 0,0287$ \\
\hline Espessura Centro & $14,85 \mathrm{~mm}$ & $12,73 \mathrm{~mm}$ & $2,12 \mathrm{~mm}$ & $14,27 \%$ & 0,0059 \\
\hline Perímetro Cervical & $38,15 \mathrm{~mm}$ & $32,34 \mathrm{~mm}$ & $5,81 \mathrm{~mm}$ & $15.22 \%$ & $* 0,025$ \\
\hline Área Cervical & $66,44 \mathrm{~mm}^{2}$ & $46,97 \mathrm{~mm}^{2}$ & $19,47 \mathrm{~mm}^{2}$ & $29,30 \%$ & $* 0,059$ \\
\hline Área total & $108,25 \mathrm{~mm}^{2}$ & $84,12 \mathrm{~mm}^{2}$ & $24,13 \mathrm{~mm}^{2}$ & $22,29 \%$ & $* 0,008$ \\
\hline
\end{tabular}

* Diferença estatisticamente significante

Os gráficos abaixo mostram a comparação entre os grupos quanto a espessura do topo do rebordo, espessura do centro do rebordo, perímetro do rebordo, área cervical e área total do rebordo alveolar
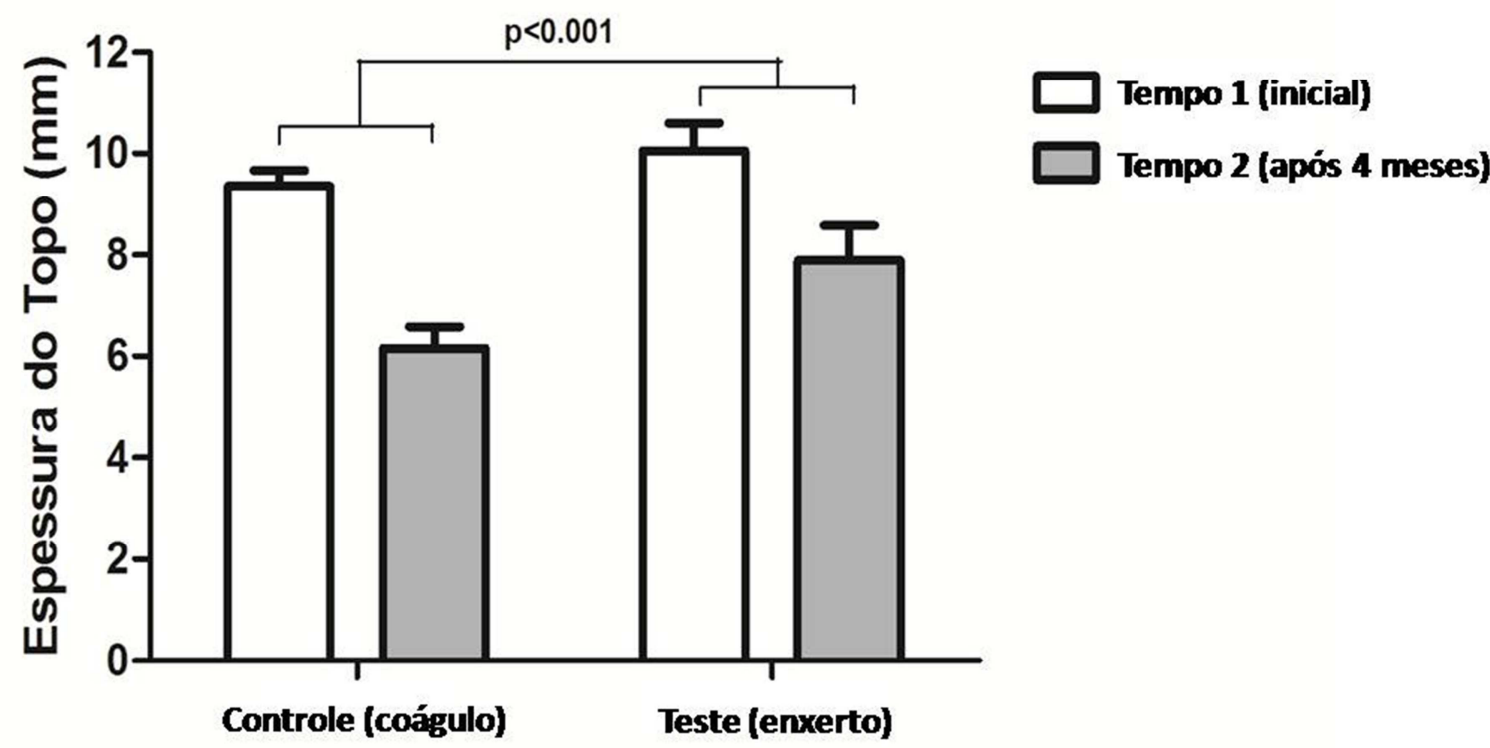

Gráfico 3. Comparação entre as espessuras do topo do rebordo alveolar antes (tempo 1) e 4 meses após a exodontia (tempo 2). A perda em espessura no topo do rebordo foi significantemente maior no grupo controle $(\mathrm{p}<0,001)$. 


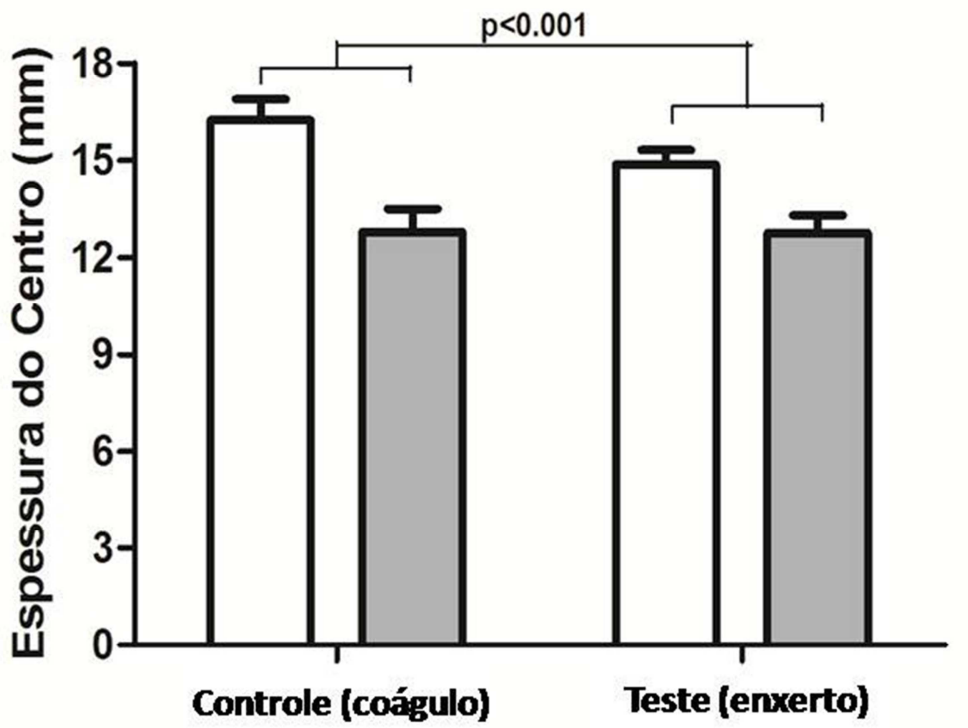

Tempo 1 (inicial)

Tempo 2 (após 4 meses)

Gráfico 4. Comparação entre as espessuras do centro do rebordo alveolar antes (tempo 1) e 4 meses após a exodontia (tempo 2). A perda em espessura do centro do rebordo foi significantemente maior no grupo controle $(\mathrm{p}<0,001)$.

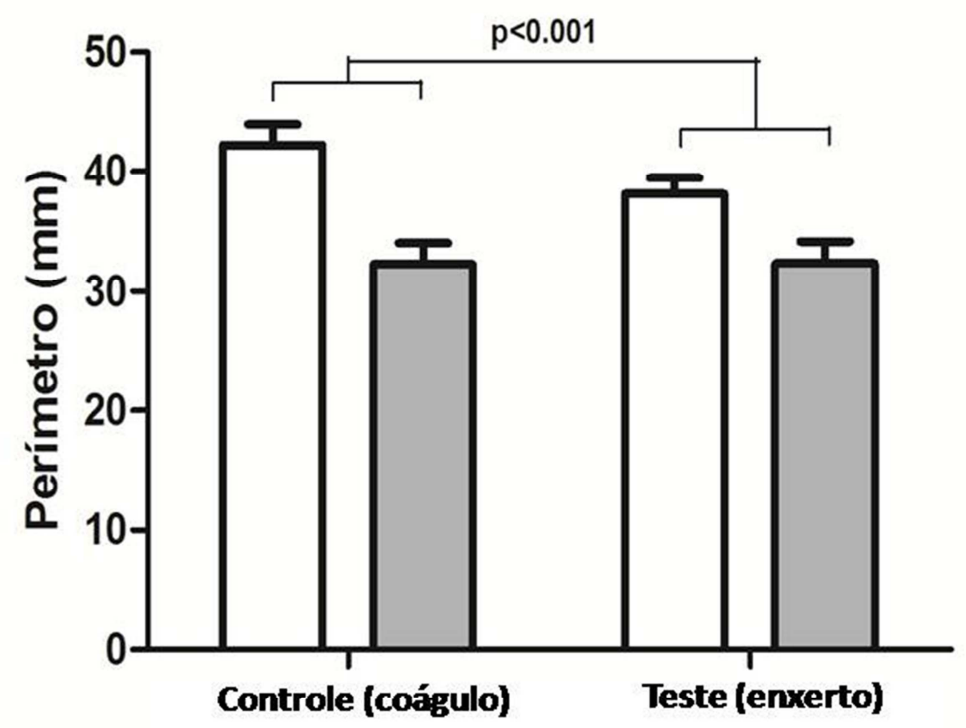

$\square$ Tempo 1 (inicial)
$\square$ Tempo 2 (após 4 meses)

Gráfico 5. Comparação entre o perímetro do rebordo alveolar antes (tempo 1) e 4 meses após a exodontia (tempo 2). O perímetro do rebordo diminuiu significantemente no grupo controle $(\mathrm{p}<0,001)$. 


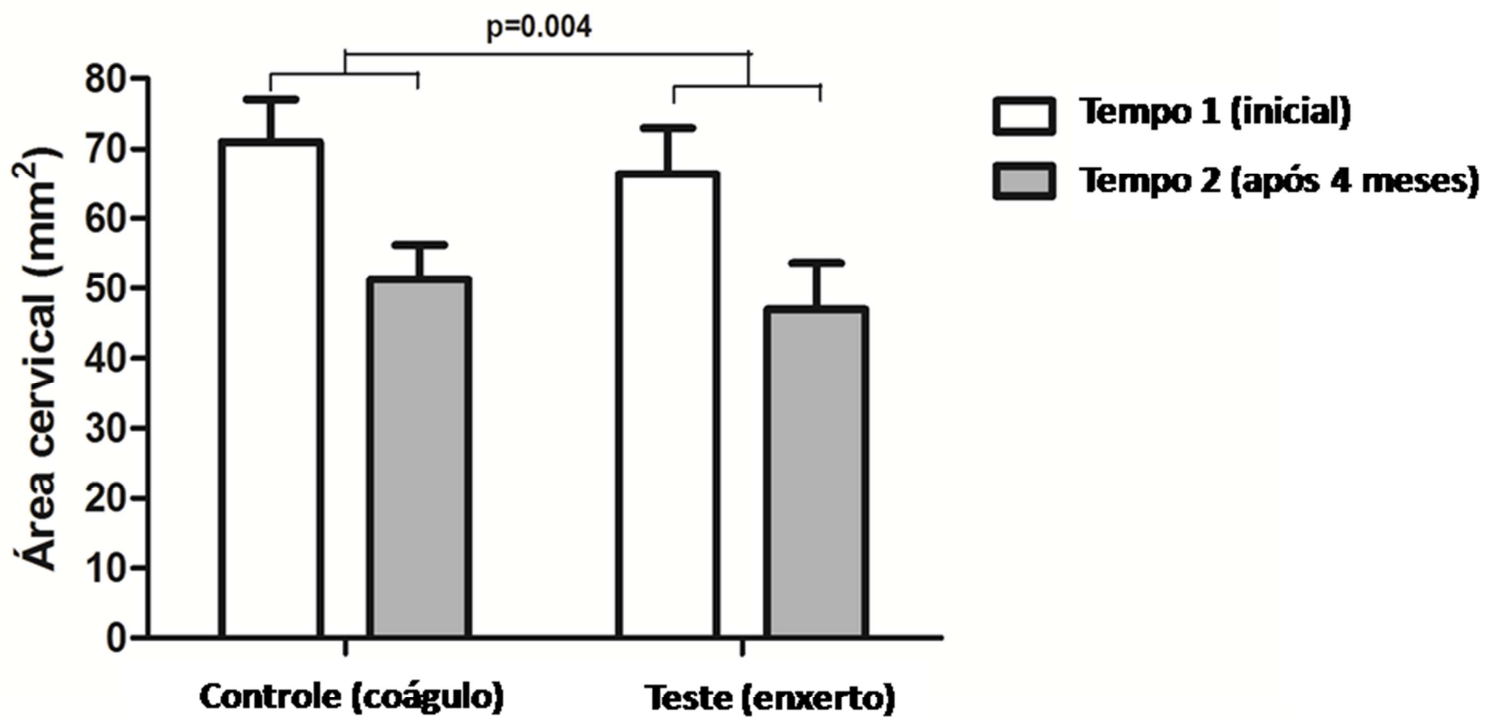

Gráfico 6. Comparação entre as áreas cervicais antes (tempo 1) e 4 meses após a exodontia (tempo 2). Houve área cervical do rebordo diminuiu significantemente mais no grupo controle $(p<0,001)$.

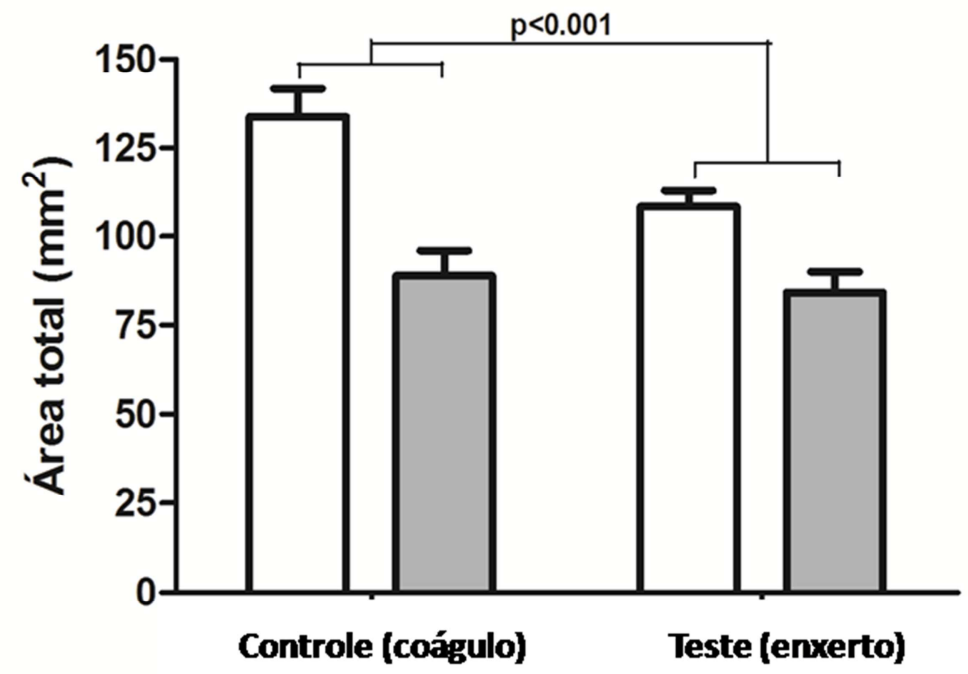

Tempo 1 (inicial)

Tempo 2 (após 4 meses)

Gráfico 7. Comparação entre as áreas totais do rebordo alveolar antes (tempo 1) e 4 meses após a exodontia (tempo 2). Houve uma diminuição da área total significantemente maior no grupo controle $(\mathrm{p}<0,001)$. 



\subsection{AMOSTRAS HISTOLÓGICAS}

\subsubsection{GRUPO CONTROLE}

Nas amostras obtidas do grupo controle (figura 1 e 2), foi possível observar a neoformação óssea, com trabéculas ósseas e células viáveis em seu interior (osteócitos). Nos espaços medulares, presentes principalmente no espaço central do corte, é possível observar a grande presença de vasos sanguíneos, com alguns vasos dilatados, denotando a intensa vascularização na área de reparação.

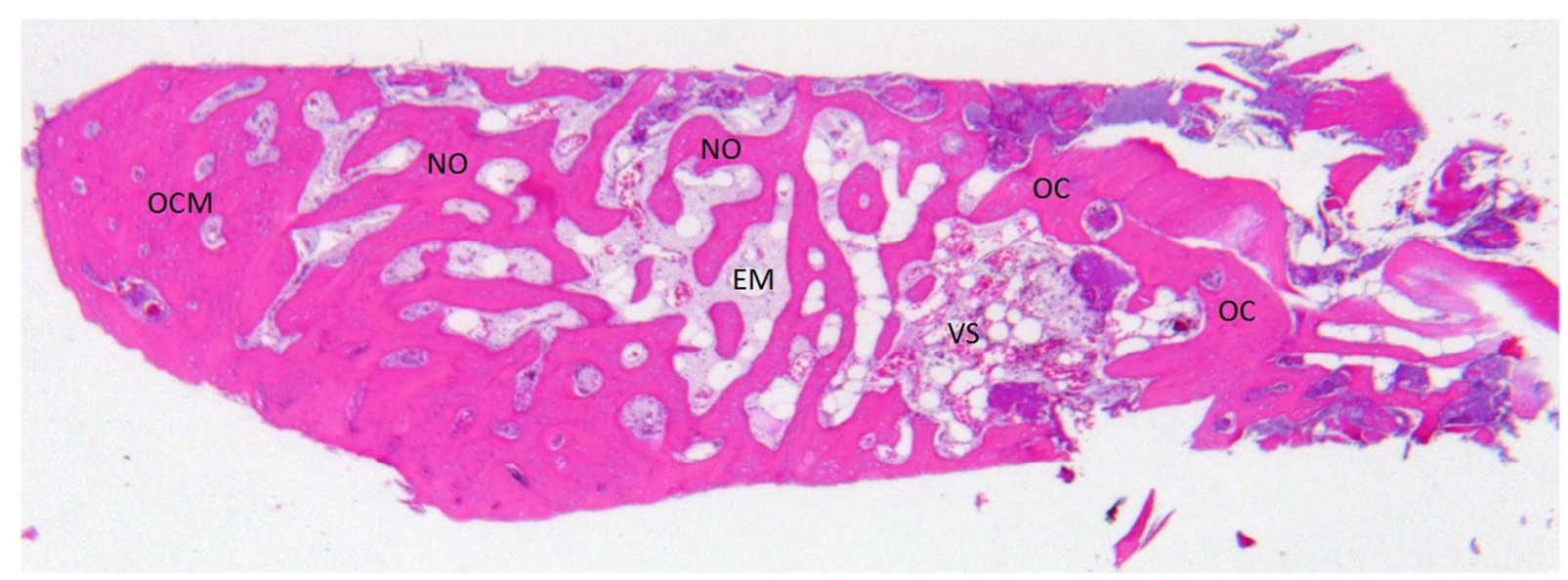

Figura 9. Figura 1. Imagem de alvéolo não enxertado (grupo controle). Uma camada de tecido ósseo cortical foi formada na parte coronal do alvéolo (OC). Na parte central do alvéolo, o trabeculado ósseo com a presença de grandes espaços medulares (EM) e vasos sanguíneos (VS) caracterizam a presença do novo osso (NO) Também pode-se observar presença de osso cortical (OCM) remanescente na parte apical do alvéolo. H.E. (Aumento original x 4) 



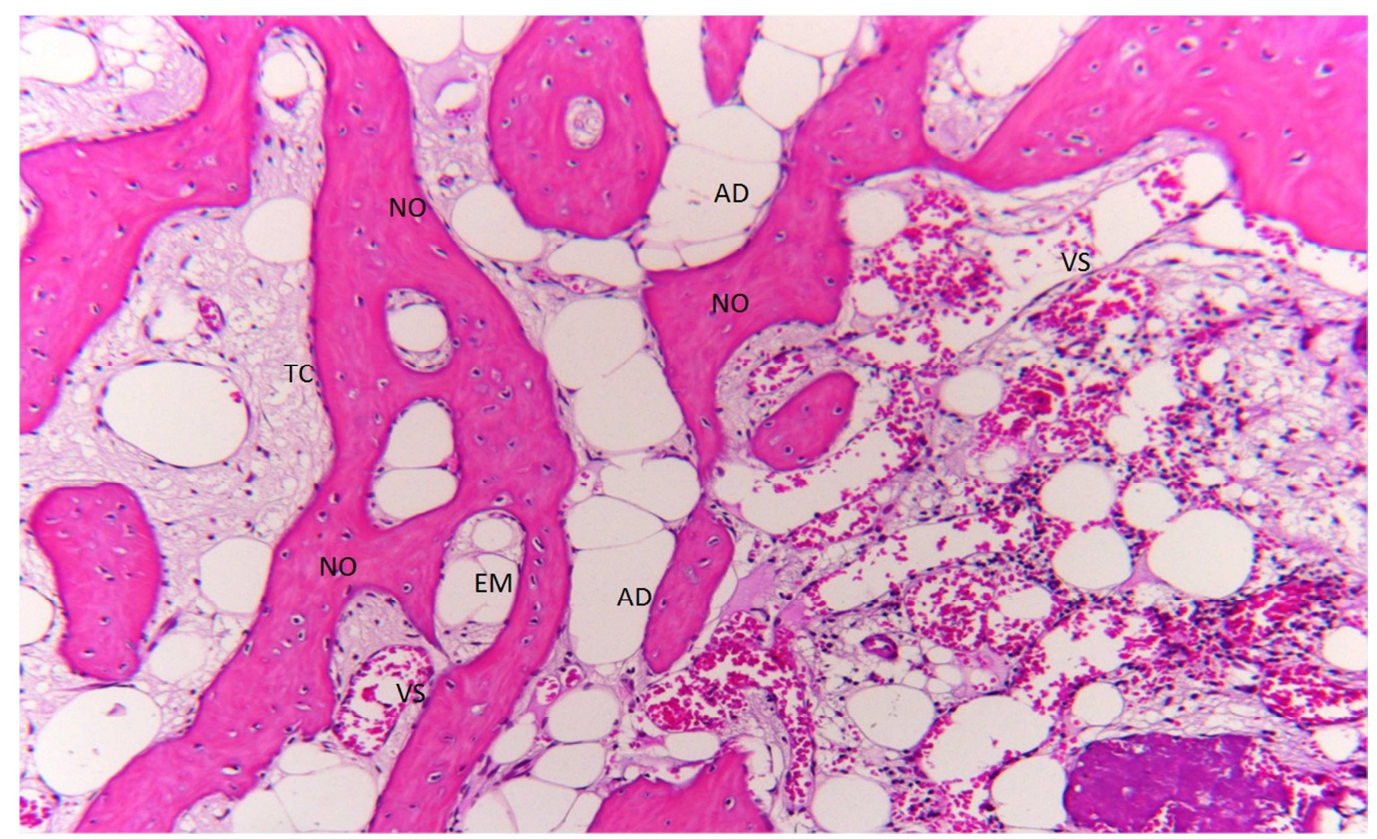

Figura 10. Figura 2. Imagem de alvéolo não enxertado (grupo controle). Podemos observar osso primário (NO), caracterizado por fibras colágenas dispersas e presença de inúmeros osteócitos. Ao redor, presença de osteoblastos, indicando contínua neoformação óssea. Também é possível observar tecido conjuntivo (TC) com presença de células mesenquimais, adipócitos (AD), amplos espaços medulares (EM) e grande quantidade de vasos sanguíneos (VS) H.E. (Aumento original x 10)

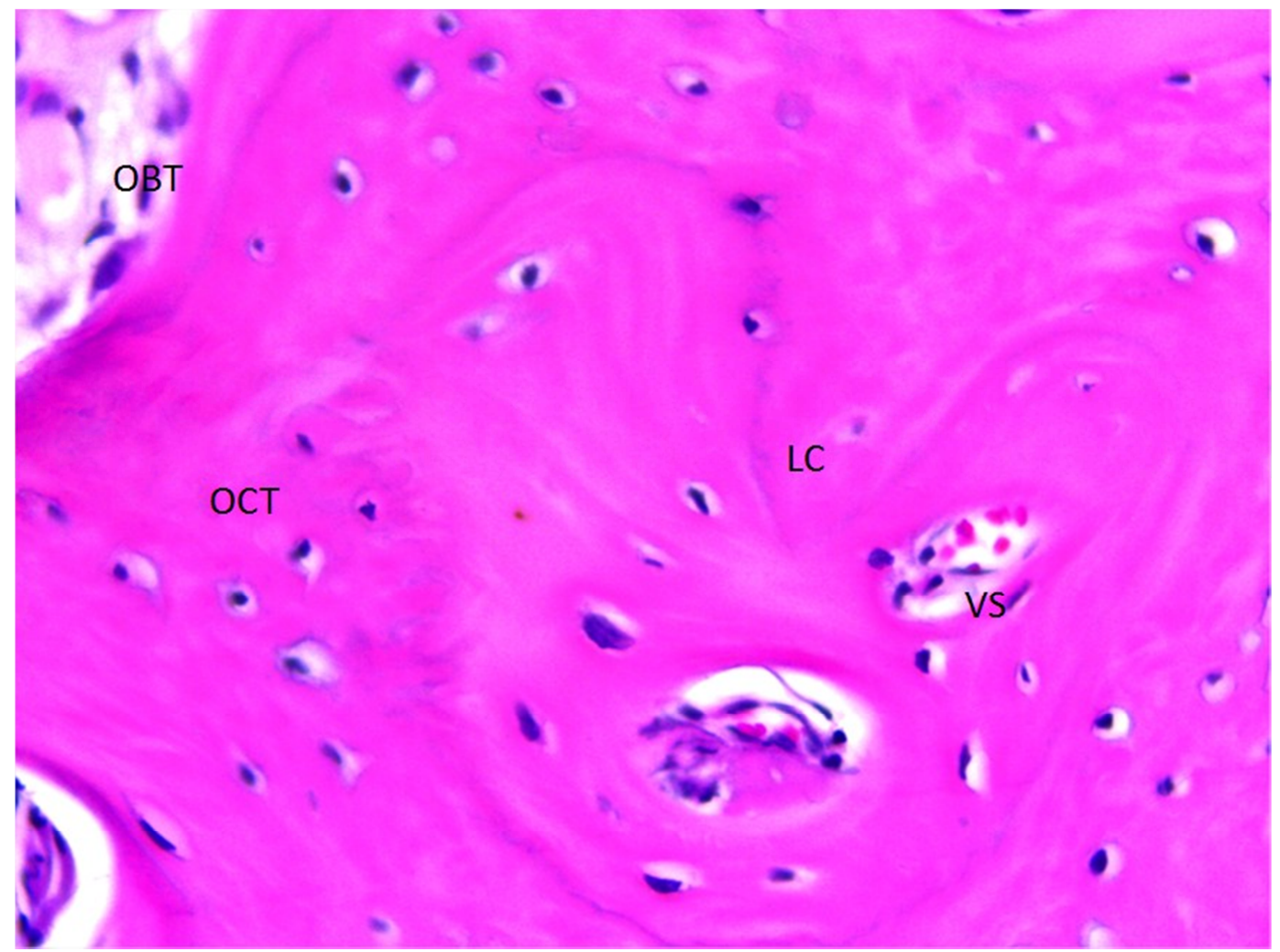

Figura 11. Figura 3. Imagem do alvéolo não enxertado (grupo controle). Em destaque, osso neoformado com a presença de osteócitos (OCT), vasos sanguíneos e linhas cimentantes (LC), que demonstram que, após 4 meses, já houve remodelação do tecido ósseo neoformado. Na margem óssea, pode-se observar osteoblastos (OBT). H.E. (Aumento original x 14) 



\subsubsection{GRUPO TESTE}

Nas amostras retiradas do grupo teste foi possível observar neoformação óssea, com trabéculas ósseas e células viáveis em seu interior (osteócitos). Novo osso também pode ser visto ao redor das partículas remanescentes do biomaterial (Orthogen ${ }^{\circledR}$ ), mostrando sua capacidade de osteoindução. Também foi possível observar formação óssea no interior dos poros do biomaterial, mostrando que sua estrutura física e tamanho dos poros favoreceu o povoamento da área com células osteoprogenitoras e proporcionando boa integração entre o biomaterial e o novo osso.

Uma grande quantidade de vasos sanguíneos pode ser observada, mostrando que, mesmo após 4 meses, ainda há uma remodelação da área.

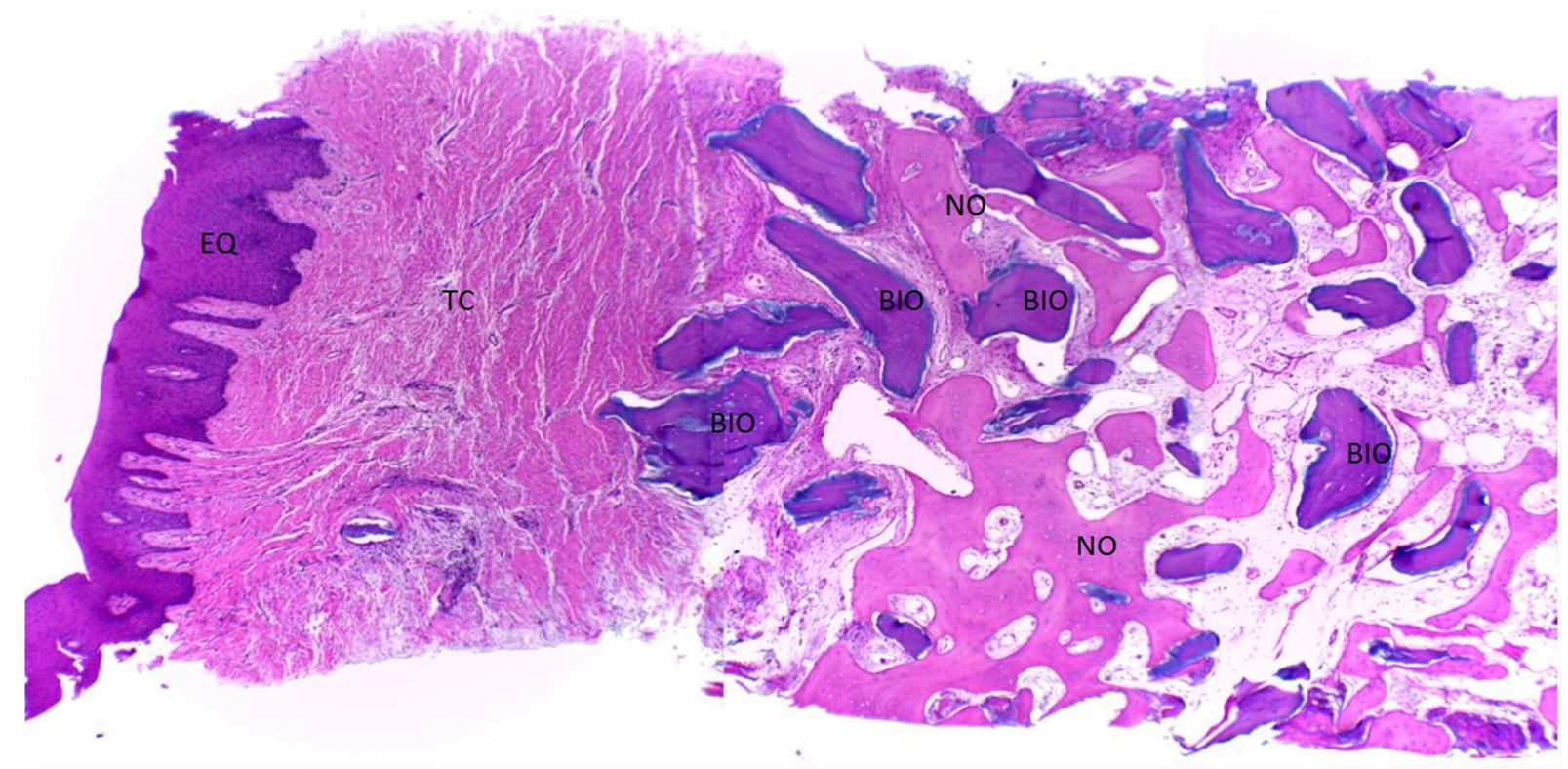

Figura 12. Imagem do alvéolo enxertado com o biomaterial (grupo teste) após 4 meses. Podemos observar, da esquerda para direita, o epitélio gengival queratinizado (EQ), tecido conjuntivo denso (TC) e o trabeculado do novo osso formado (NO) na vizinhança das partículas do biomaterial (BIO) H.E. (Aumento original $x 4$ ) 



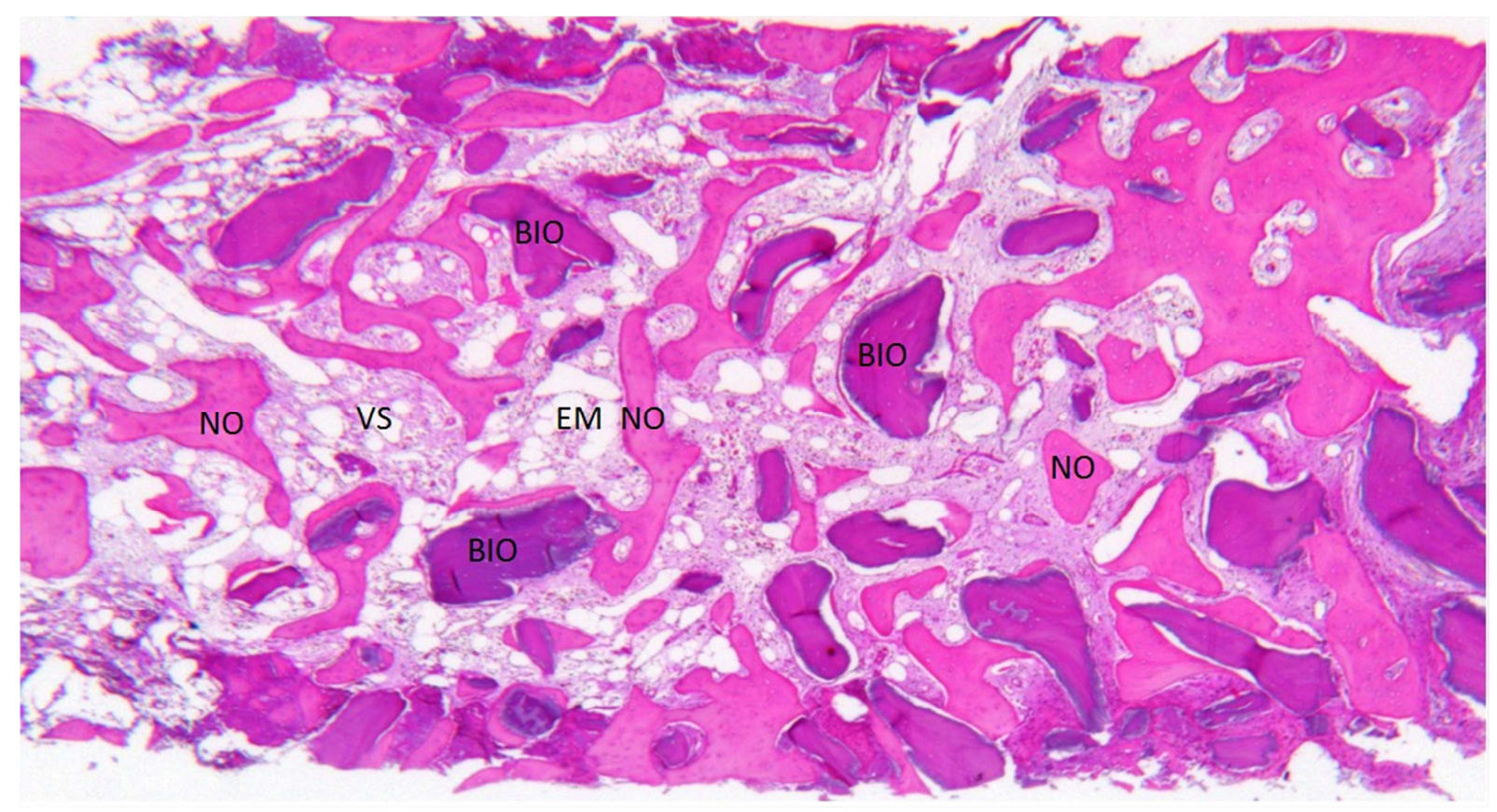

Figura 13. Fotomicrografia do alvéolo enxertado com o biomaterial (grupo teste), após 4 meses. Podemos observar a ilhas de neoformação óssea (NO) ao redor das partículas de biomaterial (BIO), presença de vasos sanguíneos e espaços medulares, ausência de células gigantes e sinais inflamatórios. H.E. (Aumento original x 4)

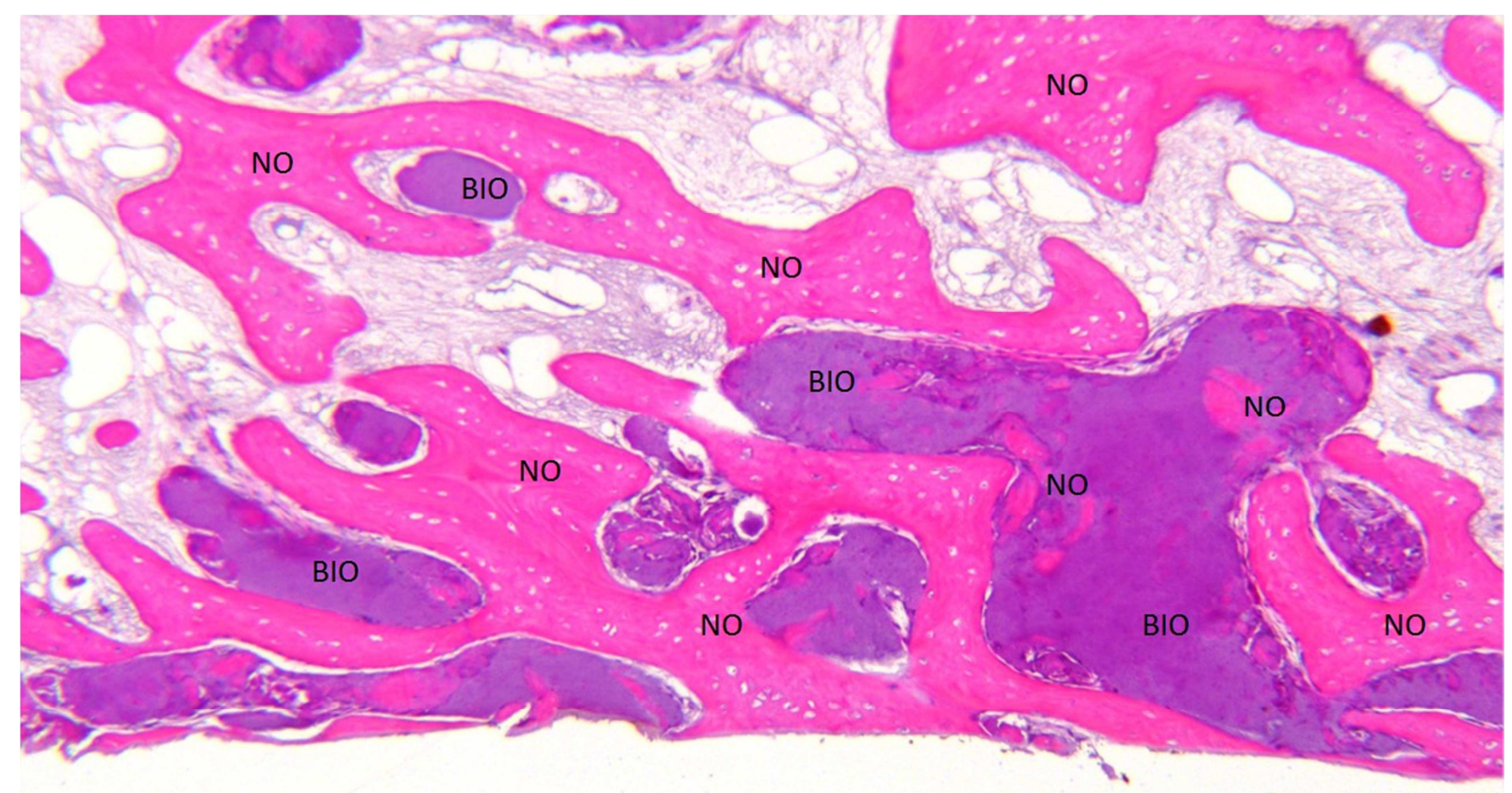

Figura 14. Imagem do alvéolo enxertado com o biomaterial (grupo teste), após 4 meses. No detalhe, pode-se observar formação de novo osso na superfície das partículas do biomaterial (BIO), demonstrando a integração do enxerto como osso. H.E. (Aumento original x 10) 



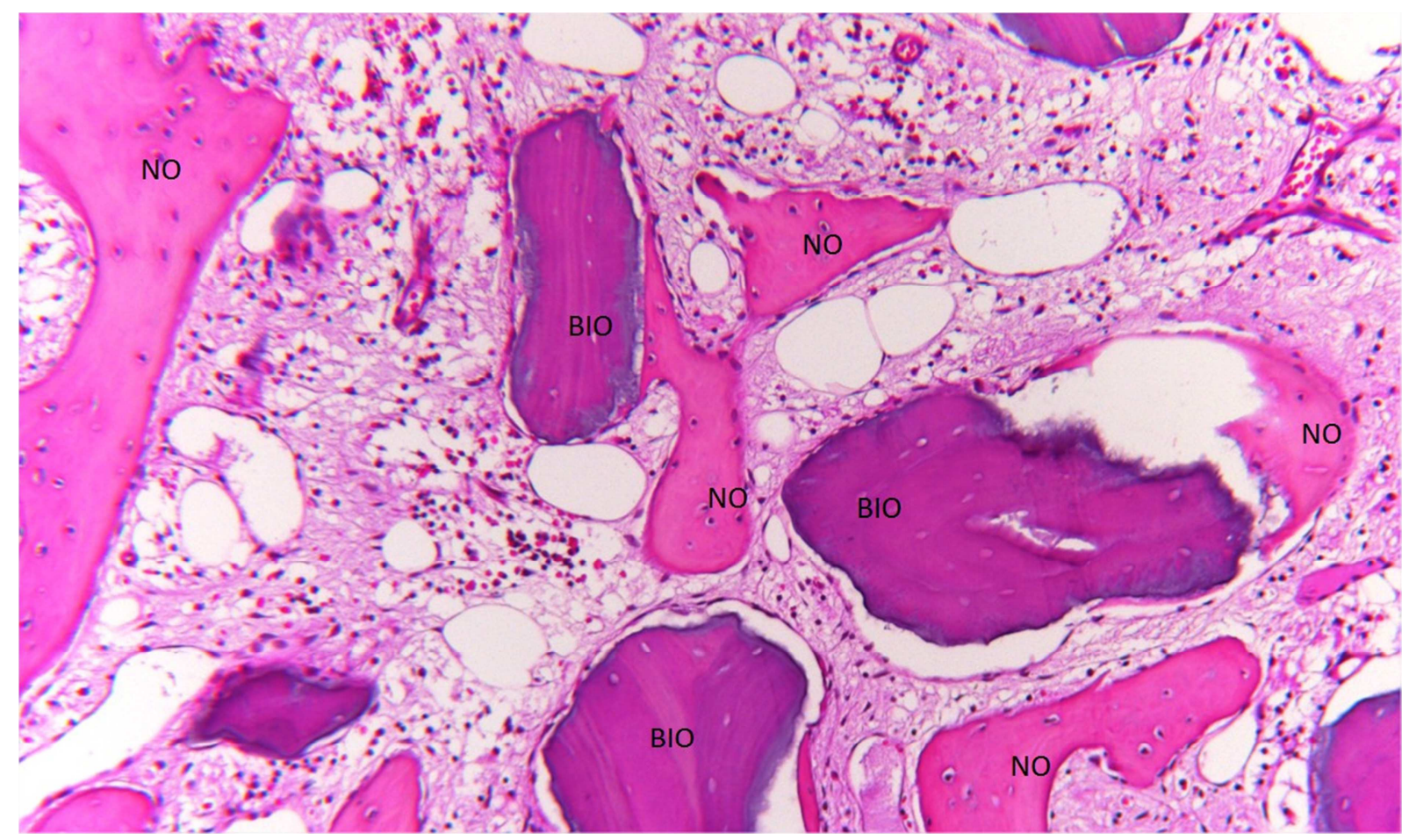

Figura 15. Imagem do alvéolo enxertado com o biomaterial (grupo teste), após 4 meses. É possível observar as partículas do biomaterial com lacunas de hawship (espaços ocupados pelos antigos osteócitos) e neoformação óssea (NO) ao redor das partículas do biomaterial (BIO), mostrando seu potencial de osteocondução e osteoindução. H.E. (Aumento original x 14) 




\section{DISCUSSÃO}

\subsection{EXODONTIA MINIMAMENTE TRAUMÁTICA}

No presente estudo, um dispositivo para extração minimamente traumática foi utilizado para realizar as exodontias das raízes residuais, com o intuito de preservar ao máximo as paredes alveolares, na tentativa de diminuir a remodelação fisiológica que ocorre no rebordo após as exodontias. Este dispositivo possibilita o tracionamento da raíz residual, no sentido apico-coronal, apoiando nos dentes laterais, evitando qualquer tipo de movimento de báscula que possa alargar o alvéolo, comprimir os vasos sanguíneos presentes nas paredes alveolares e é um procedimento que não necessita de elevação do retalho mucoperiostal.

Embora a confecção de retalho mucoperiostal não apresente diferença significante nas alterações dimensionais do rebordo alveolar pós-extração por alguns trabalhos (Araujo e Lindhe, 2009; Blanco et al., 2011; Caneva et al.), alguns autores relataram que a simples exposição da tábua óssea pela elevação desse retalho é suficiente para gerar um estímulo de reabsorção óssea com resultados significantes (Blanco et al., 2008; Jeong et al., 2007; Yaffe et al., 1994). Além disso, Kim et al. (2011) constatou que procedimento cirúrgico de extração sem a elevação de retalho diminui significantemente o desconforto e o edema pós-operatório. Diante disso, nossa metodologia se propôs a realizar o procedimento de extração "minimamente traumático", evitando ao máximo a exposição e o comprometimento da tábua óssea vestibular e palatina.

Durante o estudo, o dispositivo Extrator Atraumático Neodent (Neodent ${ }^{\circledR}$, Brasil) possibilitou a extração das raízes de maneira ágil e precisa, sendo que 15 do total de 20 raízes foram extraídas em no máximo 3 minutos, contanto a partir do início da utilização das brocas no conduto radicular até a saída da raiz do alvéolo dentário. Geralmente o procedimento de extração de raízes residuais em área anterior demanda considerável tempo clínico e extrema cautela, visto que o alargamento do alvéolo e o desgaste ósseo para conseguir apoio para a extração pode gerar traumatismo local, o que pode provocar frenestrações ou perda da tábua óssea vestibular, influenciando negativamente o resultado final da reabilitação com implantes. No presente estudo, o dispositivo extrator utilizado simplificou o processo, tornando o procedimento mais ágil e menos invasivo. Em apenas 2 dos casos, situação em que as raízes estavam muito fragilizadas pelo tecido cariado, o tracionador não foi estabilizado de 
maneira suficiente para tracionar as raízes, porém, essas raízes foram extraídas com o auxílio de outros instrumentos, tomando extrema cautela e o procedimento ocorreu sem maiores problemas.

A eficácia de um dispositivo de extração atraumática similar, chamado Benex (Hager\&MeisingerGmbH, Neuss, Germany e Helmut ZepfMedizintechnik, GmbH, Tuttlingen, Alemanha), foi avaliada na literatura. Esse dispositivo, que tem como principal objetivo realizar uma exodontia atraumática, foi utilizado sem qualquer manipulação do osso alveolar, sendo que a extração ocorre através de um dispositivo que é inserido no canal radicular previamente preparado com brocas helicoidais. Os autores concluíram que o dispositivo promoveu sucesso em $83 \%$ dos casos e, em casos de raízes muito cariadas, onde não é possível utilizar o fórceps, esse dispositivo pode simplificar o procedimento. Os autores também citaram que a maioria das técnicas de exodontia (com exceção do tracionamento ortodôntico) pode causar, mesmo que em pequena quantidade, uma expansão do osso alveolar, podendo resultar em uma remodelação mais acentuada da área (Muska et al., 2013).

Em nosso estudo, as exodontias foram realizadas 4 meses antes do momento de instalação dos implantes nos alvéolos. Porém, em muitos casos, pode-se instalar o implante imediatamente após a exodontia. Segundo Lazzara (1989), Garber et al. (2001), e Kubilius et al. (2012), a exodontia atraumática ajuda a evitar danos ao tecido remanescente, permitindo a manutenção do volume ósseo e do tecido mole adjacente, necessários para suportar o implante imediato, sem o comprometimento funcional e estético da reabilitação, possibilitando a implantação na mesma posição e com inclinação parecida com a do dente natural.

Fiamengui Filho et al. (2014b) descreveram um caso clínico onde foi realizada a exodontia atraumática utilizando o dispositivo de extração atraumática Neodent $\left(\right.$ Neodent ${ }^{\circledR}$, Brasil), instalação imediata do implante e provisionalização imediata. Após a exodontia, os autores observaram que o dispositivo agilizou o procedimento e colaborou para preservação dos tecidos duros e moles adjacentes, o que possibilitou a instalação de um implante e a obtendo estética imediata com a confecção de uma coroa provisória parafusada. Os autores concluíram que os procedimentos propiciaram qualidade e conforto ao paciente, pois foram realizados de maneira rápida e minimamente invasiva. 


\subsection{ALTERAÇÕES NO REBORDO ALVEOLAR PÓS- EXODONTIA}

O conhecimento sobre o processo de reparo em áreas de extração, incluindo as alterações que ocorrem no rebordo alveolar remanescente é de extrema importância para o planejamento e sucesso da futura reabilitação com implantes dentários.

A dinâmica e magnitude dessas alterações foram investigadas em estudos em animais (Cardaropolli et al., 2003; Araújo e Lindhe, 2005) e humanos (Devlin e Sloan, 2002; Schropp et al., 2003). Tais estudos mostraram que a maioria das alterações ocorre nos três primeiros meses de cicatrização, com uma média de reabsorção no sentido horizontal de 5-7 mm nos primeiros 12 meses. Simultaneamente à cicatrização dos tecidos e formação de novo osso no interior do alvéolo dentário, há uma acentuada reabsorção das paredes do alvéolo, sendo mais acentuada no sentido horizontal e na parede vestibular (Lekovic et al., 1998; Schropp et al., 2003; Araújo e Lindhe, 2005). Esse processo de reabsorção resulta em uma parede menor e fina e o efeito disso é a mudança de posição do rebordo para uma posição mais lingual/palatina com perda significante de tecido ósseo nos primeiros três meses após a cirurgia (Schropp et al., 2003). Dessa forma, pode ocorrer o comprometimento estético e funcional das próteses convencionais ou implantossuportadas, a partir da limitação do espaço protético, inviabilizando a instalação de um implante na posição ideal ou de uma reconstrução protética adequada.

Araújo e Lindhe (2005), em um estudo em cães, observaram que muitas alterações ocorrem nas primeiras 8 semanas após a exodontia, sendo que, primeiramente, há uma grande ação osteoclástica na crista óssea, ou porção coronal, das paredes vestibular e lingual do alvéolo, resultando na reabsorção/remodelação no sentido vertical (altura) dessas áreas, especialmente na parede vestibular. Da mesma forma, há uma reabsorção óssea do alvéolo no sentindo horizontal, reduzindo a espessura do tecido ósseo. Assim, os autores sugeriram que a reabsorção das paredes laterais do alvéolo ocorre em duas etapas simultâneas: na primeira etapa, o osso antigo é reabsorvido e substituído por uma nova matriz óssea, resultando em uma acentuada redução das paredes ósseas em altura; em uma segunda etapa, ocorre a reabsorção do osso das superfícies das paredes laterais em direção ao centro do alvéolo.

O real motivo para a remodelação, que ocorre no alvéolo após a exodontia, ainda não é conhecido (Van der Weijden et al., 2009), porém sabe-se que atrofia por desuso, diminuição da vascularização sanguínea e inflamação local tem grande papel neste complexo processo 
que envolve fatores estruturais, funcionais e fisiológicos. Além disso, o micro trauma causado no momento da exodontia pode acelerar essas alterações (Pagni et al., 2012).

Após a exodontia, um processo de reparo considerado fisiológico se inicia no alvéolo, através da remodelação tecidual, levando às alterações dimensionais que envolvem tanto o tecido ósseo quanto o tecido mole. No presente estudo, essas alterações foram estudas em indivíduos separados em dois grupos. No grupo controle, o alvéolo após a exodontia da raiz foi preservado apenas com a manutenção do coágulo e, no grupo teste, o alvéolo foi preenchido com o biomaterial de origem bovina (Orthogen ${ }^{\circledR}$, Baumer, Brasil). Em ambos os grupos o alvéolo foi selado com um enxerto gengival livre tendo como área doadora o palato do paciente.

Para estudar as alterações no rebordo, moldagens foram realizadas e modelos de gessos foram confeccionados antes dos procedimentos iniciais e após 4 meses de acompanhamento, visando estudar as transformações ocorridas nas áreas de exodontia. $\mathrm{O}$ método escolhido é pouco invasivo, não expõe o paciente a qualquer tipo de radiação desnecessária, é de fácil aplicação e já foi validado por outros estudos (Fickl et al, 2008a, 2008b). Outros estudos com características semelhantes já foram realizados, porém utilizando tomografias computadorizadas para realizar as medidas no rebordo. No presente estudo, porém, por questões éticas, não foi possível utilizá-las. É interessante ressaltar que, apesar dos modelos de gesso não possibilitarem a identificação e diferenciação entre os tecidos duros e moles, sabe-se que a remodelação gengival é mínima nesses casos, muitas vezes menor que $1 \mathrm{~mm}$ (Schropp et al., 2003), o que nos possibilita supor que a maioria das alterações ocorridas foram em tecido duro. Cuidados devem ser tomados no momento das moldagens e no vazamento do gesso, uma vez que toda a acurária das medidas depende diretamente desses modelos.

Assim, com os modelos prontos, os mesmos foram escaneados e imagens tridimensionais digitais dos modelos foram criadas. Para realizar as medidas, as imagens dos modelos foram analisados no programa Orthoanalyzer ${ }^{\circledR}$ e, em cada um dos modelos digitais , um corte transversal foi simulado, no centro do espaço do rebordo a ser estudado. Com o intuito de prevenir quaisquer tipos de distorções, ferramentas do programa Orthoanalyzer ${ }^{\circledR}$ foram utilizadas para realizar as medidas, que foram classificadas como: espessura do topo do rebordo, espessura do centro do rebordo, perímetro cervical do rebordo, área cervical e área total do rebordo. 
Após 4 meses de reparo, no grupo controle, os resultados deste estudo mostraram evidentes alterações nas medidas do rebordo, com diminuição de 34,22\% na espessura do topo do rebordo (perda média de 3,2mm), 20,96\% na espessura do centro do rebordo ( perda média de 3,4mm), 23,54\% no perímetro cervical (perda média de 9,94mm) e 33,40\% da área cervical (perda média de $19,7 \mathrm{~mm}^{2}$ )e $33,4 \%$ da área total do corte realizado (perda média de $44,7 \mathrm{~mm}^{2}$ ). Esses dados são semelhantes aos encontrados por Van der Weijden et al. (2009), que, através de uma revisão sistemática da literatura, mostraram que uma perda média de $3,8 \mathrm{~mm}$ de espessura do rebordo pode ser esperada em alvéolos cicatrizados naturalmente. Isso mostra que, mesmo com o uso da exodontia atraumática e o selamento do alvéolo com o EGL, as alterações no rebordo não puderam ser impedidas, principalmente as que ocorreram no lado vestibular (figura 7).

No grupo teste, onde o alvéolo foi preenchido com o biomaterial (Orthogen ${ }^{\circledR}$, Baumer, Brasil), alterações também foram notadas, com diminuição nas medidas do rebordo alveolar, com uma perda de 21,49\% de espessura do topo do rebordo (perda média de 2,16 $\mathrm{mm}$ ), $14,27 \%$ de perda em espessura no centro do rebordo (perda média de 2,12mm), 15,22\% do perímetro cervical do rebordo (média de 5,81mm), 29,30\% da área cervical (perda média de $19,47 \mathrm{~mm}^{2}$ ) e $22,29 \%$ da área total do corte realizado (perda média de $24,13 \mathrm{~mm}^{2}$ ). Esses resultados são similares aos encontrados por Cardaropoli et al.,(2005) e Nevins et al.,(2006), que relataram, em situações similares, uma perda média de $20 \%$ na espessura do rebordo e, demonstram que o preenchimento do alvéolo não impediu por completo perdas no rebordo alveolar após a exodontia.

Porém, quando comparamos as perdas que ocorreram nos dois grupos, notamos que as diferenças entre eles foram estatisticamente significantes, evidenciando uma menor perda no rebordo no grupo teste (enxerto). Quando comparamos a espessura do centro do rebordo alveolar, notamos que nos casos onde o biomaterial foi usado, houve perda $1,3 \mathrm{~mm}$ menor. Esses resultados são similares aos encontrados por Fickl et al. (2008), que também associaram o enxerto ósseo bovino desproteinado com o enxerto gengival livre e obtiveram melhor preservação do rebordo no grupo com o biomaterial (diferença de 1,5 mm). Assim, é possível afirmar que o uso do biomaterial não foi capaz de impedir as alterações que ocorrem no rebordo alveolar, porém, colaborou para uma melhor manutenção do mesmo, com menor perda das dimensões iniciais (figura 8). 
Aspectos importantes na reconstrução alveolar pós exodontia foram discutidos por Bartree (2001) e um dos pontos importantes citados foi a importância do uso de biomateriais e sua gradativa reabsorção pelo organismo, o que não impede a osseointegração de implantes na área. Como vantagens do uso desses biomateriais, o autor destacou a diminuição da remodelação alveolar, melhora na densidade óssea da área e a maior disponibilidade óssea para instalação de um implante na área enxertada. O autor também menciona o uso da matriz óssea bovina desmineralizada como boa opção, pois esse material mantém a forma microscópica do osso, criando no local um ambiente capaz de viabilizar a revascularização e a osteocondução. Como conclusão, o estudo afirmou que o uso de biomateriais para prevenir as alterações indesejadas do rebordo após a exodontia é um procedimento previsível, conveniente e com custo acessível.

Clinicamente, foi possível notar em nosso estudo uma boa manutenção na altura do rebordo alveolar, com boa presença de mucosa ceratinizada em ambos os grupos. Esse fato pode estar associado ao uso do Enxerto Gengival Livre (EGL) para selamento do alvéolo, sem a necessidade do deslocamento de um retalho e conseqüente alteração na posição da linha mucogengival. O sucesso dos enxertos gengivais ocorreu em todos os casos sem maiores problemas. Esses achados estão de acordo com os encontrados por Jung et al. (2004), que, após 3 semanas de acompanhamento, relataram a integração de 99,7\% dos enxertos gengivais utilizados para fechamento do alvéolo.

Fickl et al. (2008b), em um estudo experimental em cães, mostrou que a incorporação de um substituto ósseo em alvéolo de extração tem um impacto limitado sobre o processo biológico, principalmente no que diz respeito à tábua óssea vestibular. A tábua óssea vestibular é substituída por nova matriz óssea, guiada pelo arcabouço criado pelo material de substituição óssea. Além disso, a associação com um enxerto gengival livre ajuda a prevenir o colapso de tecido mole, por auxiliar na estabilidade mecânica e na manutenção do arcabouço.

Embora nossos resultados mostrem reduções dimensionais estatisticamente significantes intra grupos e entre os grupos, evidenciando a dificuldade em impedir as transformações que ocorrem no rebordo após a exodontia, em todos os 20 casos foi possível a instalação de um implante em posição favorável, e, após 6 meses, esses implantes apresentavam-se clinicamente osseointegrados. Esses resultados podem estar também relacionados à manutenção da parede óssea vestibular durante os procedimentos de exodontia minimamente traumática e a preservação do tecido mole adjacente. 
Porém, no grupo controle, futuros procedimentos de manipulação tecidual como um possível aumento de volume do rebordo utilizando enxerto de tecido conjuntivo subepitelial podem ser necessários para otimizar a estética e diminuir a evidente depressão na parede vestibular do rebordo (figura 7).

\subsection{ANÁLISE DAS AMOSTRAS HISTOLÓGICAS}

No presente estudo, após 4 meses de reparo pós-exodontia e no ato cirúrgico de instalação do implante dentário, amostras ósseas dos dois grupos foram obtidas, utilizando uma broca trefina de $3 \mathrm{~mm}$ (figura 3). A obtenção das amostras foi realizada durante a preparação do leito ósseo para a instalação do implante dentário e foi feita com cuidado, uma vez que o alargamento em excesso do alvéolo poderia prejudicar a estabilidade do implante. $\mathrm{O}$ local de coleta foi selecionado de acordo com a posição ideal do futuro implante no rebordo, uma vez que a confecção de uma futura prótese implanto suportada estética e funcional depende diretamente da instalação deste implante em posição tridimensional ideal. Desse modo, o local de coleta óssea nem sempre foi coincidente com o centro do alvéolo cicatrizado, e, em alguns casos, ocorreu mais para palatina, principalmente nos casos onde as exodontias ocorreram em incisivos ou caninos. Por esse motivo, para a análise histológica, optamos pela forma descritiva e ilustrativa, pois não haveria a possibilidade de realizar a histomorfometria de maneira confiável.

Quando comparamos as imagens dos cortes histológicos do grupo controle (coágulo) e grupo teste (enxerto), notamos diferenças evidentes entre elas. No grupo controle, uma ponte de novo osso foi formada na parte cervical do alvéolo (figura 9), separando o tecido conjuntivo gengival do resto do alvéolo. Já no grupo teste (enxerto), não foi possível identificar a presença dessa ponte de tecido ósseo, e sim partículas de biomaterial entre o tecido conjuntivo gengival e a parte cervical do alvéolo (figura 12). Esses achados são semelhantes aos citados por Cardaropolli et al (2003), Lindhe et al (2005;2013), que descreveram, após 2 meses de cicatrização do grupo não enxertado, a presença de uma ponte óssea separando o tecido a área do alvéolo pós extração do tecido gengival marginal. A ausência dessa ponte óssea nos casos enxertados pode estar relacionada à quantidade de biomaterial inserida no alvéolo, que, em alguns casos, pode ter sido colocado em excesso e dificultado essa formação (Lindhe et al., 2013). 
Através da observação lâminas, é possível identificar uma cicatrização mais avançada no grupo controle (figura 9 e 10), com grande quantidade de formação de novo osso no espaço alveolar e áreas incrementais (figura 11), demonstrando que após a formação óssea inicial, áreas de remodelação já podem ser observadas. Já no grupo enxertado, a cicatrização parece ter ocorrido de maneira mais lenta, com muitos espaços entre as ilhas ósseas e grande quantidade de partículas de biomaterial remanescentes (figura 12 e 13). Essas características estão de acordo com o que já foi descrito por Araujo el at. (2008), mostrando que o preenchimento de alvéolos frescos com biomateriais pode atrasar a cicatrização e a remodelação do tecido. Porém, como citado por Lindhe et al. (2013), essa menor diminuição na remodelação do tecido causada pela presença das partículas de biomaterial pode ser benéfica, visto que contribui para uma menor "atrofia" do rebordo alvéolo quando comparado ao grupo controle, e não atrapalha a osseointegração de implantes instalados na área enxertada.

Estudos mostram que a utilização de enxerto ósseo inorgânico em alvéolos de extração, é significativamente eficaz na formação óssea, com diminuição na porcentagem do processo de reabsorção óssea alveolar (menos de 20\%), quando se compara com alvéolos nos quais nenhum biomaterial foi utilizado. Após 3 meses, é notável a presença de partículas do biomaterial envoltas por osso neoformado, demonstrando que o biomaterial serve de arcabouço para formação de novo osso (Cardaropoli et al.,2005; Nevins et al., 2006).

Nas áreas enxertadas, a grande maioria das partículas de biomaterial estava envolta por novo osso (osteoindução), e, em alguns locais, foi possível notar formação óssea no interior das partículas do biomaterial, demonstrando sua capacidade de osteocondução (figura 6 e 7). Assim, em todas as imagens obtidas, foi possível observar uma boa incorporação do biomaterial pelo organismo, não apresentando, após 4 meses, áreas de fibrose ou intenso exudato inflamatório. Segundo Hallman et al. (2001), a tendência é que o biomaterial seja absorvido de forma lenta, e que, gradativamente, as partículas do mesmo diminuam e dêem lugar para uma maior quantidade de osso neoformado. 
7 CONCLuSÕes 



\section{CONCLUSÕES}

Considerando as limitações metodológicas presentes neste estudo, podemos concluir que:

- A utilização do biomaterial Orthogen ${ }^{\circledR}$ para preenchimento dos alvéolos frescos pode minimizar a perda óssea do rebordo alveolar após a extração dentária

- As características clínicas e histológicas apresentadas pelo biomaterial Orthogen ${ }^{\circledR}$ demonstraram a possibilidade de seu uso com segurança em alvéolos pósextração, e não contraindicam sua utilização em sítios que serão submetidos à instalação de implantes;

- Em nenhum dos grupos foi possível impedir totalmente a reabsorção fisiológica que acontece no rebordo alveolar após a exodontia.

- $\quad$ O Kit de Extração Atraumática Neodent ${ }^{\circledR}$ foi capaz de simplificar o procedimento de exodontia das raízes residuais, tornando o procedimento simples, mais rápido e menos traumático.

- Outros estudos devem ser realizados para verificar qual a melhor técnica para a preservação alveolar pós-exodontia 




\section{REFERÊNCIAS}

Araújo MG, Lindhe J. Dimensional ridge alterations following tooth extraction. An experimental study in the dog. J Clin Periodontol 2005; 32(2): 212-8.

Araújo MG, Sukekava F, Wennström JL, Lindhe J. Ridge alterations following implant placement in fresh extraction sockets: an experimental study in the dog. J Clin Periodontol 2005;32(6):645-52.

ARAÚJO, M. G. e LiNDHE, J. Ridge alterations following tooth extraction with and without flap elevation: an experimental study in the dog. Clin Oral Implants Res, v. 20, n. 6, Jun, p.5459. 2009.

Bartee BK. Extraction site reconstruction for alveolar ridge preservation. Part1: rationaleandmaterialsselection. J Oral Implantol2001;27(4):187-93.

Blanco, J., MAREQUe, S., et al.Vertical and horizontal ridge alterations after tooth extraction in the dog: flap vs. flapless surgery. Clin Oral Implants Res, v., n., Feb 11.

Botticelli D, BerglundhT, Buser D, Lindhe J. Appositional bone formation in marginal defects at implants. Clin Oral Implants Res 2003;14(1):1-9.

Cardaropoli G, Araújo M, Hayacibara R, Sukekava F, Lindhe J. Healing of extraction sockets and surgically produced - augmented and non-augmented - defects in the alveolar ridge. An experimental study in the dog. J Clin Periodontol 2005;32(5):435-40.

Cardaropoli G, Araújo M, Lindhe J.Dynamics of bone tissue formation in tooth extraction sites: an experimental study in dogs. J Clin Periodontol 2003;30(9):809-18.

Chen ST, Buser D. Clinical and esthetic outcomes of implants placed in postextraction sites. Int J Oral Maxillofac Implants 2009;24Suppl:186-217.controversy? J Periodontol. 2001 Mar;72(3):417-21.

Cosyn J, Hooghe N, De Bruyn H. A systematic review on the frequency of advanced recession following single immediate implant treatment. J Clin Periodontol 2012;39(6):5829 .

de Carvalho PSP; Rosa AL; Bassi APF; Pereira LAVD. Biomateriais aplicados a Implantodontia. Rev Implantnews 2010;7(3a-PBA):56-65. 
Devlin H, Sloan P. Early bone healing events in the human extraction socket. Int J Oral MaxillofacSurg 2002;31(6):641-5.during tooth extraction. Stomatologia. 2012;14(1):3-11.

Dym H, Weiss A. Exodontia: tips and techniques for better outcomes. Dent Clin North Am 2012;56(1):245-66.

Fiamengui Filho, JF et al. Aspectos periodontais relacionados ás próteses provisórias unitárias implantossuportadas. Perionews 2014;8(2):151-156.

Fiamengui Filho, JF et al. Reabilitação estética com implante imediato após exodontia minimamente traumática. Full dent. Sci 2014;5(19):417-21.

Fickl S, Zuhr O, Wachtel H, Bolz W, Huerzeler MB.Hard tissue alterations after socket preservation: an experimental study in the beagle dog. Clin Oral Implants Res 2008;19(11):1111-8.

Fickl S, Zuhr O, Wachtel H, Stappert CF, Stein JM, Hürzeler MB.Dimensional changes of the alveolar ridge contour after different socket preservation techniques. J Clin Periodontol 2008;35(10):906-13.

Garber DA, Salama H, Salama MA. Two-stage versus one-stage-is there really a controversy? J Periodontol. 2001 Mar;72(3):417-21.

Gália CR, Lourenço AL, Rosito R, Macedo CAS, Camargo LMAQ. Caracterização físicoquimica do enxerto de osso bovino liofilizado. Rev. bras. Ortho; 46(4): 444-451, 2011.

Hämmerle CH, Jung RE, Yaman D, Lang NP. Ridge augmentation by applying bioresorbable membranes and deproteinized bovine bone mineral: a report of twelve consecutive cases. Clin Oral Implants Res 2008;19(1):19-25.

Huynh-Ba G, Pjetursson BE, Sanz M, Cecchinato D, Ferrus J, Lindhe J, et al.Analysis of the socket bone wall dimensions in the upper maxilla in relation to immediate implant placement. Clin Oral Implants Res 2010;21(1):37-42.

Irinakis T. Rationale for socket preservation after extraction of a single-rooted tooth when planning for future implant placement. J Can Dent Assoc 2006; 2(10):917-22.

JeOng, S. M., ChOI, B. H., et al. Flapless implant surgery: an experimental study. Oral Surg Oral Med Oral Pathol Oral Radiol Endod, v. 104, n. 1, Jul, p.24-8. 2007. 
Jung RE, Siegenthaler DW, Hämmerle CH.Postextraction tissue management: a soft tissue punch technique. Int J Periodontics Restorative Dent 2004;24(6):545-53.

KIM, H. R., CHOI, B. H., et al. A comparative study on the extractions of partially impacted mandibular third molars with or without a buccal flap: a prospective study. J Oral Maxillofac Surg, v. 69, n. 4, Apr, p.966-70.

Kubilius M, Kubilius R, Gleiznys A. The preservation of alveolar bone ridge during tooth extraction. Stomatologija. 2012;14(1):3-11. Review.

Lambert F, Vincent K, Vanhoutte V, Seidel L, Lecloux G, Rompen E. A. Methodological approach to assessing alveolar ridge preservation procedures in humans: hard tissue profile. $\mathbf{J}$ Clin Periodontol 2012;39(9):887-94.

LAZZARA, RJ. Immediate implant placement into extraction sites: surgical and restorative advantages. Int J Periodontics Restorative Dent, v. 9, n. 5, p.332-43. 1989.

Lekovic V, Camargo PM, Klokkevold PR, Weinlaender M, Kenney EB, Dimitrijevic B, et al.Preservation of alveolar bone in extraction sockets using bioabsorbable membranes. $\mathbf{J}$ Periodontol 1998;69(9):1044-9.

Lindhe J, Cecchinato D, Donati M, Tomasi C, Liljenberg B. Ridge preservation with the use of deproteinized bovine bone mineral. Clin Oral Implants Res 2013 [Epub 2012 Apr 4]

Muska E, Walter C, Knight A, Taneja P, Bulsara Y, Hahn M. Atraumatic vertical tooth extraction: a proof of principle clinical study of a novel system. Oral Surg Oral Med Oral Pathol Oral Radiol 2013;116(5):303-10.

Nevins M, Camelo M, De Paoli S, Friedland B, Schenk RK, Parma-Benfenati S,et al. A study of the fate of the buccal wall of extraction sockets of teeth with prominent roots. Int $\mathbf{J}$ Periodontics Restorative Dent 2006;26(1):19-29.

Pagni G, Pellegrini G, Giannobile WV, Rasperini G.Postextraction Alveolar Ridge Preservation: Biological Basis and Treatments. Int J Dent 2012 [Epub 2012 Jun 12]

Paolantonio M, Dolci M, Scarano A, d'Archivio D, diPlacido G, Tumini V, et al. Immediate implantation in fresh extraction sockets. A controlled clinical and histological study in man. $\mathbf{J}$ Periodontol 2001;72(11):1560-71.

Perelman-Karmon M, Kozlovsky A, Liloy R, Artzi Z. Socket site preservation using bovine bone mineral with and without a bioresorbable collagen membrane. Int J Periodontics Restorative Dent 2012;32(4):459-65. 
Schropp L, Wenzel A, Kostopoulos L, Karring T. Bone healing and soft tissue contour changes following single-tooth extraction: a clinical and radiographic 12-month prospective study. Int J Periodontics Restorative Dent 2003;23(4):313-23.

Simion M, Baldoni M, Rossi P, Zaffe D. A comparative study of the effectiveness of e-PTFE membranes with and without early exposure during the healing period. Int J Periodontics Restorative Dent 1994;14(2):166-80.

Tan WL, Wong TLT, Wong MCM, Lang NP. A systematic review of post-extractional alveolar hard and soft tissue dimensional changes in humans. Clin Oral Impl Res 2012;23(Suppl5):1-21.

Van der Weijden F, Dell'Acqua F, Slot DE. Alveolar bone dimensional changes of postextraction sockets in humans: a systematic review. J Clin Periodontol 2009;36(12):1048-58.

Yaffe, A, FINE, N, et al. Regional accelerated phenomenon in the mandible following mucoperiosteal flap surgery. J Periodontol, v. 65, n. 1, Jan, p.79-83. 1994.

Yalcin S, Aktas I, Emes Y, Kaya G, Aybar B, Atalay B. A technique for atraumatic extraction of teeth before immediate implant placement using implant drills. Implant Dent 2009;18(6):464-72. 
Anexo 



\section{Faculdade de Odontologia de Bauru-USP}

\section{PROJETO DE PESQUISA}

Título: Avaliaçăo do rebordo alveolar apos exodontia utilizando enxerto osseo alobeno

Área Temática:

Pesquisador: Jurge Franciscu Flanengui Felino Versăo: 2

Instituiçăo: Faculdade de Odontologia de Bauru-USP $\quad$ CAAE:03016412.7.0000.5417

\section{PARECER CONSUBSTANCIADO DO CEP}

Número do Parecer: 48497

Data da Relatoria: $\quad 27106 / 2012$

\section{Apresentaçăo do Projeto:}

Trata-se de um projeto de doutorado que será desenvolvido sob orlentaçăo do Prof. Dr. Sebastiáo Luiz Aguiar Greghi. Paclentes, na faixa etária de 18 a 65 anos, que procurarem a Faculdade de Odontologia de Bauru-USP para tratamento e necessitarem realizar de 1 a 3 exodontias de dentes pré-molares, caninos ou incisivos por periodontite crónica, cárie dental ou fratura radicular serăo convidados a participar do estudo. Serăo selecionados para este estudo 20 alvéolos dentários, divididos em dois grupos mediante o tipo de abordagem: grupo 1:. recobrimento do alvélo através de tecido reposicionado do palato e suturado com fio vicryl 4.0 ETHICON, INC):

Grupo 2: o ORTOGENQ será inserido na área receptora e ligeiramente condensado. O alvélo enxertado será recoberto com tecido reposicionado do palato atraves do deslocamento de um retalho pediculado e suturado com fio Vicryl 4.0 (ETHICON, INC).

\section{Objetivo da Pesquisa:}

Verificar se a utilizaçăo do biomaterial Orthogen irá favorecer a manutençăo do rebordo alveolar e se é efetivo na neoformaçăo ossea no interior do alveolo.

\section{Avaliaçăo dos Riscos e Beneficios:}

Os riscos são restritos ao procedimento de exodontia realizado por indicaçăo clínica. O beneficio, agora apresentado, é a reposiçăo de elementos dentários perdidos, por meio da instalaçăo de implantes osseointegrados e futuras próteses sobre implante. Apos a instalaçăo dos implantes, os pacientes serão encaminhados para a clínica integrada da FOBIUSP para a confeçăo das coroas protéticas.

\section{Comentários e Consideraçðes sobre a Pesquisa:}

Trata-se de um estudo interessante, pois estudará um método para se obter um rebordo alveolar propicio para a instalaçào de implantes em posiçăo favorável.

\section{Consideraçס̄es sobre os Termos de apresentaçăo obrigatória:}

O TCLE fol adequado como solicitado.

\section{Recomendaçбes:}

Nåo há 


\section{Conclusões ou Pendências e Lista de Inadequações:}

Considerando que a documentação está de acordo com a Resolução 196/96, sou de parecer favorável a aprovaçăo deste projeto.

\section{Situação do Parecer:}

Aprovado

\section{Necessita Apreciação da CONEP:}

Não

\section{Considerações Finais a critério do CEP:}

O CEP acata o parecer do relator e considera o presente projeto APROVADO.

BAURU, 02 de Julho de 2012

$$
\text { Assinado por: }
$$

Flávio Augusto Cardoso de Faria 